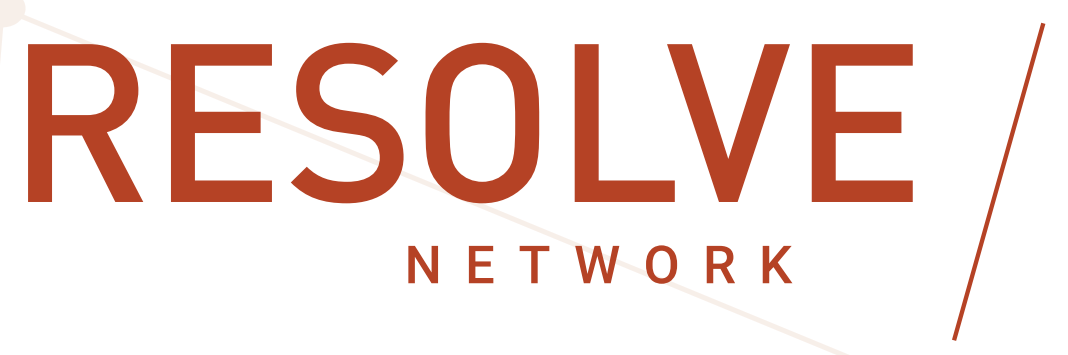

\title{
Mistrust and Imbalance:
}

The Collapse of Intercommunal Relations and the Rise of Armed Community Mobilization on the Niger-Mali Border

Dr. Rahmane Idrissa \& Bethany McGann 


\section{CONTENTS}

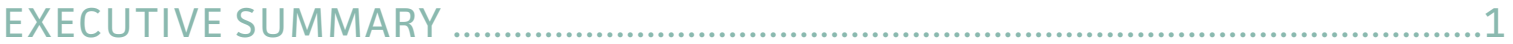

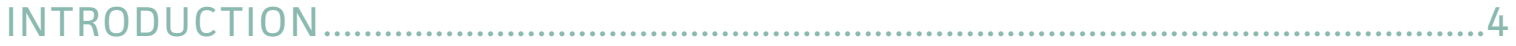

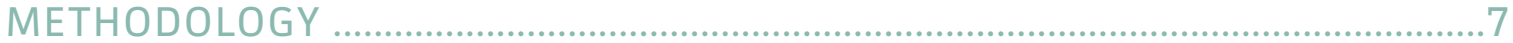

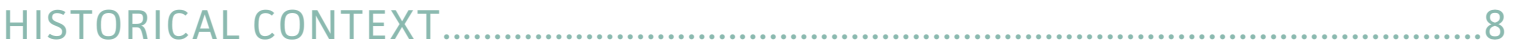

A precarious balance: people, place, power ...................................................... 8

Agents of conflict: armed actors and (once limited) violence ..................................13

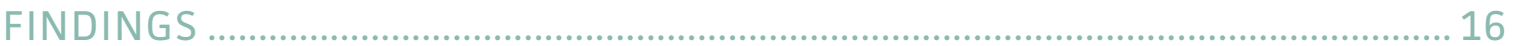

Violence and mistrust ....................................................................................... 16

Interdependence and the state .................................................................. 19

REVISITING BALANCE:

HISTORICAL AND POLITICAL TRENDLINES ..................................................... 23

Historical change ......................................................................................... 24

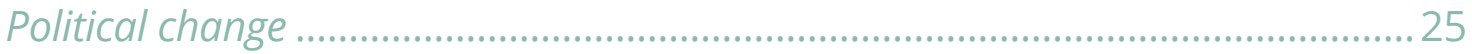

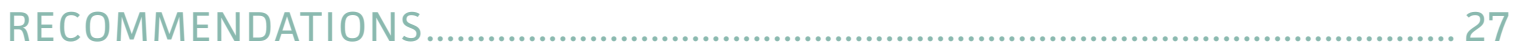

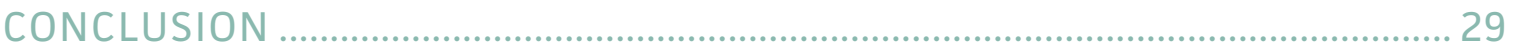

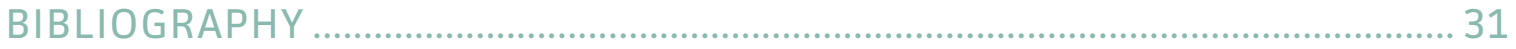

The views expressed in this publication are those of the authors. They do not necessarily reflect the views of the RESOLVE Network, the U.S. Institute of Peace, or any entity of the U.S. government. 


\section{EXECUTIVE SUMMARY}

Across much of the Sahel-Sahara, ${ }^{1}$ where the footprint of regular administration and state presence is light, communities' relations and interrelations are key to resolving contentious issues and preserving peace. However, these relations are shaped and informed by histories and traditions which may breed conflict and grievance, especially when competition for space and resources is heightened by ecological stress, population pressure, and widespread insecurity, as in recent decades. Community relations form precarious balances through mechanisms such as traditional institutions or the exchange economy despite persistent pressure points and occasional crises. These balancing mechanisms operate at the nexus of formal and informal governance actors, implemented through complex political bargains and social norms managing low-level conflict both with and without state actor intervention. The contemporary shocks to the system presented by violent extremism and militant security threats have ruptured these relationships and resulted in a spiral of violence. ${ }^{2}$

Similar dynamics are evident in areas of southwestern Niger, along its northern border with Mali, and its western border with Burkina Faso. The border area of Mali, Niger, and Burkina Faso is a site of endemic violence. The area is punctuated by anti-state attacks, by both the self-proclaimed Islamic State (IS) and al-Qaeda's Group for Support of Islam and Muslims (JNIM), the targeted killing of traditional chiefs, and attacks on markets and other socioeconomic convening locales that otherwise serve as central mechanisms for the preservation of normalized intercommunal interactions. In addition, foreign military interventions (especially France's Operation Barkhane) and asymmetric insurgent warfare pits multiple state and non-state actors equipped with heavy weaponry against one another, adding another level of insecurity and threat to local communities. 2019 and 2020 saw the worst spikes in violence against civilians since the internationalization of the conflict in 2013 (marking the start of the French operation). A significant number of deaths are attributed to state security forces, including state-backed militias. ${ }^{3}$

In this context, converging and diverging agendas of parties to the violence have further confused efforts to engender and restore peaceful relations. Among these parties, community-based armed groups $(\mathrm{CBAGs})^{4}$ of Fulani and Tuareg ethnicity have aligned themselves with outside actors carrying out operations in the region-including French and U.S. military forces carrying out operations under a counterterrorism framework and jihadist actors - out of choice, coercion, or in some cases both. ${ }^{5}$ Generally, Fulani armed groups have allied with Salafist militants for tactical, but also ideological, reasons. Meanwhile,

1 A West African region extending from Mauritania to Chad through northern Mali, northern Burkina Faso, and northern Niger.

2 Morten Bøås, Abdoul Wakhab Cissé, and Laouali Mahamane, "Explaining Violence in Tillabéri: Insurgent Appropriation of Local Grievances?," The International Spectator 55, no. 4 (2020): 118-132, https://doi.org/10.1080/03932729.2020.1833567.

3 Human Rights Watch, "Sahel: End Abuses in Counterterrorism Operations," February 13, 2021, https://www.hrw.org/news/2021/02/13/ sahel-end-abuses-counterterrorism-operations.

4 Lauren Van Metre, From Self-Defense to Vigilantism: A Typology Framework of Community-Based Armed Groups (Washington, D.C.: RESOLVE Network, 2019), https://doi.org/10.37805/cbags2019.3.

5 The issue of coercion is related to the relationship the communities have with groups operating around them, in some cases more of a hostage situation than mutually beneficial association. 
Tuareg armed groups have generally allied with the French army for tactical advantage. These are alignments by choice. But some recruits are coerced, taken hostage by jihadist actors to ensure the loyalty of their home community. Such hostages are subjected to indoctrination and may embrace the cause of their abductors. ${ }^{6}$ However, it is difficult to discern who among the community is participating in the violence, to what end, and why, which impedes efforts to address the cycle of escalation in the region.

Building on other research reports in RESOLVE's Community-Based Armed Groups Series ${ }^{7}$, this report explores local perceptions regarding the nature and impact of the violence surrounding two communities in southwestern Niger: the départements ${ }^{8}$ of Ayorou and Abala, two of the three main flash points of conflict in the area (the third being Banibangou). The analysis draws findings from desk research as well as data collected from interviews and questionnaires conducted in late 2019. The report provides a summary of understanding of ongoing conflict dynamics from the most impacted communities and an insight on the knowledge and attitudes around actors participating in the violence. It hopes to inform efforts to bring an end to the violence and increase understanding of participating actors.

The study is organized against a backdrop of missed opportunities and the ever-worsening security situation in western Niger and the broader Liptako-Gourma region ${ }^{9}$. The research carried out for this report did not directly focus on CBAGs due to safety considerations and confusion among local communities as to who exactly was involved in the violence. However, this study contributes to the broader evidence base of how local dynamics shape and extend opportunity for CBAG formation and continuity and the tactics used by violent extremist organizations and other external actors to capitalize on these opportunities. Following a discussion of the context, known actors, and research findings and data analysis, the report provides recommendations for those seeking to understand the conditions for the use of non-military options in restoring peace to the region, across three areas relevant to the ongoing violence: sociopolitical and economic dynamics, sociocultural dynamics, and resultant armed group mobilization dynamics.

6 Interview with High Authority for Peace Consolidation (HACP) official, Niamey, 2019.

7 Launched in partnership with the U.S. Agency for International Development Africa Bureau, the RESOLVE Network Community-Based Armed Groups research initiative in Sub-Saharan Africa aims to provide key stakeholders with contextual information on the dynamics of community-based armed groups (CBAGs) and current, prospective, and past approaches to engage, manage, and transform them. The project grapples with a complicated series of questions and decisions negotiated by stakeholders operating in conflict-affected societies across Sub-Saharan Africa. For more, see: https://www.resolvenet.org/projects/community-based-armed-groups-sub-saharan-africa.

8 The regions of Niger are divided into 63 departments, forming a level of subnational administrative governance.

9 The continuous areas of Mali, Burkina Faso, and Niger. 


\section{Key Findings}

- The state of war in the region, waged through subterfuge, mass killings, and violence perceived by civilians as unregulated-both by the state and its enemies-has created an ambiance of mistrust and "psychosis" in the border regions. There is a broad sense of confusion within local populations regarding who the perpetrators of violence are and why they are perpetrating violence.

- This ambiance of general mistrust and "psychosis" negatively impacts the historic balancing mechanisms between and within local communities, their everyday lives, and freedom of movement. Lack of mobility is particularly challenging for pastoralist communities and further fosters contestation over sparse resources. The balancing mechanisms stem from the work of local chiefs and clerics (through intermediation), often backed up by the work of local authorities (enforcement, historically by prefects and sub-prefects who had control over gendarmerie forces, more recently by elected officials) and sustained by market relations (creating interdependence). Therefore, the mechanisms are intermediation, interdependence, and enforcement. The value of each one of those mechanisms varies in accordance with the district and the time. ${ }^{10}$

- Dissatisfaction with governance-especially from the central state-is prevalent. But the difference in outcomes between the two research sites suggests that government policy can make a difference in perceptions of the government's ability to be an effective actor in reducing intercommunal conflicts. However, government function in these rural settings is complex, where several formal and informal authorities are entangled.

- Collapse of the balancing mechanisms has removed the checks on limited violence and reprisals carried out by ethnic, caste, and identity-based militias. Without these checks, and few interlocutors who are able to safely intercede in intercommunal violence due to the presence of jihadists, score settling related to decades of resource competition and political reformation drive additional violence beneath the surface of the conflict taking place in the region.

- Relations between and within communities rest on economic interdependence, but this can be as much a source of moderation as of contestation and radicalization. When communal interdependence is premised on inequality and marginalization of one of the groups in the relationships, the potential gains of alliances with external actors to shift the balance of power in these relations might drive individual recruitment into violent extremist groups or realpolitik deal-making with violent extremist actors. In the case of "Black" Tuareg (given social and political inequality between castes) and some Fulani pastoralist groups this has resulted in their perception as a threat and perceived or actual marginalization. This threat perception is enhanced by the securitization measures implemented by state and allied forces casting suspicion on pastoralist/nomadic communities on assumptions of disloyalty due to transhumance-based livelihoods. Radicalization

10 See: Rahmane Idrissa, "Traditional authorities in Niger: Politicization and under-representation," in The Status Quo Defied. The Legitimacy of Traditional Authorities in Areas of Limited Statehood in Mali, Niger, and Libya, eds. Fransje Molenaar et al. (The Hague: Clingendael Institute, 2019), https://www.clingendael.org/pub/2019/legitimacy traditional authorities mali niger libya/. 
as well as opportunism resulted from sociopolitical inequality and marginalization but in the context of the actions of state and Jihadist forces.

- Armed groups operating in Niger have largely exhausted the recruitment drivers stemming from community-level crises. Current dynamics suggest more of a large-scale hostage-taking than active participation. Unlike Mali, CBAGs did not reach the same level of organization and establishment in Niger. Fulani self-defense militias were active before 2011, and most of the Tuareg groups, active during the rebellions, were operating on the Mali side of the border. Nevertheless, it is possible that the armed groups active in Niger post-2012 do not fit the CBAG typology and that there are likely limitations that frontier CBAGs will reach during the course of the ongoing conflict.

\section{INTRODUCTION}

In the areas surrounding the shared borders of Niger, Mali, and Burkina Faso, limited and low-level violence has long been a pattern in social and economic relations between and within communities. This was largely non-state violence caused by competition over resources, even if people were also victims of abuses from state security agents, especially on the Mali side of the border. ${ }^{11}$ This violence, and the perceptions of injustice and insecurity it was bound up with, spawned negative feelings against the state, as the place where the buck stopped, even in regions where the state has a "weak" or under-resourced presence. ${ }^{12}$ That these grievances did not, for many years, lead to extremist violence means that balancing mechanisms were successful in maintaining the status quo of infrequent, limited violence with equally limited violent intercommunal reprisals.

Inherent to this context is competition over ecological resources between herders and farmers on the one hand, and among herders on the other. In recent years, population growth and climate change shaped this competition. Strategies of access to resources are evolving in ways that may intensify competition. Competition, while occasionally flares into open conflict, has been manageable through the balancing mechanism based on intermediation, interdependence, and enforcement of a rural law-andorder system that gives customary chiefs, territorial administrators (prefects), and the gendarmerie, a form of rural police, the function that allows communities to resolve low-level conflicts through mutually agreed customary formats, sometimes including acts of violence and reprisals.

11 This area of Mali is far from the center of the state with which it is less integrated than the regions in the south-west.

12 The author put "weak" in quotation marks because it has become a trope in expert and media discourse, largely inspired by scholarly concepts such as "weak state" or "limited statehood." The concept of the state is empirically too complex to be reduced to this trope as this case study suggests. In this Nigerien story, for instance, the state includes not only the central government (which is implied in the trope) but also the territorial administration, including the prefects, the traditional chiefs who are a formal component (under the ministry of the interior) of the central government, and local elected authorities (mayors and councilors). In all these guises, the state is very much present in these locales, although not necessarily efficient in government work for a variety of political and economic reasons. 
This balance was ruptured following events that started in 2011, when a coalition led by Western militaries destroyed the regime of Col. Muammar al-Qaddafi in Libya. ${ }^{13}$ This triggered a chain of events, beginning with the return to Mali of armed men from a Tuareg subgroup of the Kidal region (northern Mali) who (re)started a rebellion there. Northern Mali was then an area where Algerian Salafist militants had found refuge after the end of the Algerian civil war of the 1990s, building a sanctuary from which, as early as the 2000s, they were able to organize the abduction of Western tourists or aid workers. Initially known under their Algerian civil-war-era names Islamic Armed Group (GIA, from the French acronym) or Salafist Group for Preaching and Combat (GSPC, from the French acronym), these groups shifted and coalesced into a variety of new vehicles, including al-Qaeda in the Islamic Maghreb (AQIM) and, of late, the Islamic State in the Greater Sahara (ISGS). ${ }^{14}$ The adoption of violent extremist Islamic ideologies and radicalizing narratives was intensified by initial franchising efforts by, and later the collapse of, the so-called Islamic State in Iraq and Syria and the subsequent dispersal of fighters, arms, and logisticians to the Sahel and North Africa. ${ }^{15}$

The Tuareg Kidal rebels initially allied with these Algerian militants and routed Mali's armed forces in 2012, aided by combatants originating from other north African countries and Mauritania. However, soon the Kidal rebels fell out with the Salafists. ${ }^{16}$ Moreover, Fulani pastoralists have traditionally engaged in transhumance at the border between Niger and Mali and often been in conflict with Tuareg groups from the Kidal and Gao region. ${ }^{17}$ These Fulani dreaded the prospect of a Tuareg state in northern Mali and the potential impact on livelihoods and political arrangements on either side of the border. ${ }^{18}$ They $^{2}$ were drawn into the conflict on the side of the Salafist militants in early 2013. Later that year, the French interventions (Operation Serval, followed by Operation Barkhane) further entrenched the Fulani in their support for the armed Salafists by enlisting the Tuareg groups as on-the-ground allies for intelligence, surveillance, reconnaissance, and theatre access purposes and encouraging the Nigerien government to support this strategy. ${ }^{19}$

The change in resource endowment-in this case political and security opportunities garnered through engagements with international armed forces and militant groups-overrode the limited (or limiting) benefits of engaging in traditional balancing mechanisms. ${ }^{20}$ Opportunity to pursue parochial agendas and score settling precipitated escalation of cycles of violence, further spurred by the parallel geopolitical

13 Scott Stewart, "Mali Besieged by Fighters Fleeing Libya," Stratfor Worldview, February 2, 2012, https://worldview.stratfor.com/article/ mali-besieged-fighters-fleeing-libya.

14 United Nations Security Council, "Islamic State in the Greater Sahara (ISGS), https://www.un.org/securitycouncil/content/ islamic-state-greater-sahara-isgs.

15 Cameron Glenn, Mattisan Rowan, John Caves, and Garrett Nada, "Timeline: the Rise, Spread, and Fall of the Islamic State," Wilson Center, The Islamists, 2016, https://www.wilsoncenter.org/article/timeline-the-rise-spread-and-fall-the-islamic-state.

16 See: Radio France Internationale, "AQMI, MUJAO, MNLA: un rapport de force complexe," July 5, 2012, https://www.rfi.fr/fr/ afrique/20120705-aqmi-mujao-mnla-rapport-force-complexe.

17 Gao region is predominantly of the ethnic-linguistic group Songhay and is adjacent to Kidal and borders north-western Niger.

18 See: Nicolas Normand, "Le Sahel peut-il retrouver la paix?," Commentaire 4, no. 164 (2018): 839-846.

19 See: Remi Cayarol, “À la frontière entre le Niger et le Mali, l'alliance coupable de l'armée française," Mediapart, November 25, 2018, https://www.mediapart.fr/journal/international/291118/la-frontiere-entre-le-niger-et-le-mali-l-alliance-coupable-de-l-armee-francaise.

Van Metre, From Self-Defense to Vigilantism. 
agendas promoted by external actors. On the one hand, Western actors engaged in counterterrorism and stabilization missions in the region. ${ }^{21}$ On the other hand, jihadist elements engaged in a mission to defeat a neocolonialist enemy and free Africa of western influence (a narrative tailored to fit local contexts). Some were perhaps also driven by financial motivations related to access to the prolific trans-Saharan smuggling and trafficking shadow economies. ${ }^{22}$ The impact of this series of events upset the fragile balance upon which inter- and intra-community peace and function rested in this part of the Sahel-Sahara. This research paper is an effort to understand that balance, what is left of it today, and where it is leaving communities in the border regions and the state of Niger, now facing the wrath of violent extremism.

The dynamics explored in this paper must be considered within the context of the history of the origins of the frustration and violence of elite Tuareg and of the fallout from the changes brought about by democratization and administrative decentralization in $1992^{23}$, which will be discussed at length in subsequent sections of this report. The wider circumstantial factors related to the allied interventions of the French and Nigerien security forces operating in and around Liptako-Gorma were not part of this research. ${ }^{24}$ It is implicitly recognized though that they have complicated, if not worsened, the regional situation through strategic bargain-making and operational alliances with regional ethnic groups and by developing rules of operation that resulted in the securitization of communities and frequent human rights abuses in eliciting intelligence.

The report is divided into four main sections: 1 ) an overview of the research methodology and limitations; (2) a review of the context, including the history of conflict and cooperation in the border regions and the armed groups known to have presence there; (3) a presentation and analysis of the research results as they relate to the situation in late 2019-early 2020;25 and (4) a review of the study that positions the analysis within the larger historical and structural context. The report concludes with recommendations derived from findings on the communities about dynamics related to armed community mobilization for restoring moderation in inter- and intracommunal relations held hostage by violent extremists.

21 Oxford Research Group, "The Military Intervention in Mali and Beyond: An Interview with Bruno Charbonneau," March 28, 2019, https:// www.oxfordresearchgroup.org.uk/blog/the-french-intervention-in-mali-an-interview-with-bruno-charbonneau.

22 IRIN News, "Briefing: The new Jihadist strategy in the Sahel," Africa Renewal, February 4, 2016, https://www.un.org/africarenewal/sahel/ news/briefing-new-jihadist-strategy-sahel; International Crisis Group, "Sidelining the Islamic State in Niger's Tillabery," June 3, 2020, https://www.crisisgroup.org/africa/sahel/niger/289-sidelining-islamic-state-nigers-tillabery.

23 Mahaman S. Tidjani Alou, "Decentralization in Niger: An Attempted Approach," Columbia University, 1999, https://www.ciesin.columbia. edu/decentralization/English/CaseStudies/Niger.pdf.

24 These interventions were responses to the activities of Salafist extremists ("terrorists" in the official Franco-Nigerien language) which also were not part of research for safety and security reasons.

25 The entirety of this research was conducted and completed before the outbreak of the global COVID-19 pandemic and thus does not speak to any changes to the context influenced by the pandemic. 


\section{METHODOLOGY}

The methods applied for this research sought to respond to questions about the climate of violence from the viewpoint of communities and perceptions of community members regarding each other and the central government versus local governance administration. The research was carried out in the départements of Ayorou and Abala, two of the three districts most exposed to the current violence in Tillabéri Region (the third locality, Banibangou, was assessed as too dangerous for research). The peril for all three comes from proximity to northern Mali. Ayorou and Abala give an understanding of how platforms for social interaction contribute to normative balance in intercommunal interactions and feature the ethnic groups participating in armed conflict throughout the region. Ayorou is a small town with an important state administration presence and a big market, making it easier for researchers to meet respondents without having to travel in remote, isolated, and potentially dangerous places. Abala is a cluster of villages harboring both sedentary communities and semi-nomadic Tuareg, Fulani, and Arabs. It has shaped the development of conflict dynamics on the Niger side.

To understand the escalatory environment characterized by a proliferation of armed groups-both statebacked and community-based-it is critical to examine the underlying contextual factors and histories of communal relations. Information, especially data on key events and timelines of armed group formation, is still difficult or impossible to collect under present conditions. Therefore the research developed a partial empirical approach that relied on surveying attitudes and perceptions through interviews and questionnaires throughout the latter half of 2019 in Ayorou and Abala. ${ }^{26}$ These primary datasets were then contextualized through desk research and interviews with resource persons, i.e. former militants, Niamey-based civil-society representatives of the local communities, and researchers.

In the primary data collection the questions focused on how resident communities understand the rise of violence, how they explain its persistence, and how they see the future. Given the nature of these questions, we developed an open-ended interview questionnaire to collect qualitative data. These questionnaires were disseminated to local elected officials, agents of the territorial administration, NGO activists, chiefs, and people close to traditional authorities in both localities. The research focused on the local communities not so much on the state and its actions (or inactions).

We conducted a small survey on inter-community relations and community perceptions of the state, applied to a total of 200 individuals in Ayorou and Abala, two of the three main flash points of the conflict area. Enumerators were hired in each of these two towns. ${ }^{27}$ We did not probe opinions on security

26 This study was enumerated during the second half of 2019, and thus the data from interviewees reflects conditions during that period of the evolving Sahelian conflict.

27 This was not easy because other projects were also conducting fieldwork-with larger resources - and the small number of individuals who could work as enumerators were all employed by them. This created a constraint which we solved by conducting all survey efforts on one day, the market day in each locality. A market day is a day in the week when a town or village is known to open its market to buyers and sellers from the surrounding district and thus an opportunity to engage a diverse selection of respondents. The advantage to this survey approach is applying the questionnaire to people from all parts of the districts. Although the exercise proved difficult since 
forces due to the difficulty of framing questionnaires about that in the tense atmosphere that prevails in the region. We also avoided asking questions about insurgents, given the "psychosis" later described in the paper. Due to safety constraints (both for us and for our respondents), we did not collect data directly on the security forces and the insurgent groups. However, we did indirectly ask questions about the performance of the branch of the security state-the gendarmerie-that is operationally closest to local populations.

A third method was the organization of a post-fieldwork focus group of resource persons, i.e. people active in Niamey-based associations that represent and lobby for communities in the border regions, including Tuareg and Fulani, and the organization Timidria. ${ }^{28}$ The objective of this focus group was to help develop the recommendations presented at the end of the paper.

\section{HISTORICAL CONTEXT}

In contextualizing the emergence and expansion of endemic intra- and intercommunal conflict in western Niger, it is critical to understand the historical underpinnings of the balancing mechanisms that served as a moderating force before violent extremist and jihadist-driven insecurity swept across the Sahel. Armed community mobilization and proliferation of armed groups occur against the backdrop of the role of traditional chiefs, hybridized governance and political arrangements, and resource-driven competition between ethnic groups manifest through political reforms and evolutions in localized governance. A precarious balance historically served to resolve conflict in the short term but laid the foundation for vulnerabilities that opportunistic non- and sub-state actors take advantage of. What follows is a review of the relationships between people, places (territorial and social), and power constructed to maintain balance, and agents of conflict.

\section{A precarious balance: people, place, power}

Niger is a landlocked country of West Africa, independent from France since 1960. It has one of the smallest economies of the region, largely dependent on commodities (uranium, groundnuts, onion, cattle) for revenue. Run by authoritarian governments in its first three decades of existence, Niger democratized in 1991. However, the authoritarian impulse remains strong in its political class, and democracy has had a troubled history in Niger. This has created political issues that have frustrated the aspirations of Nigerien citizens for efficient government work, including along the Niger-Mali border. ${ }^{29}$

marketgoers have little time or patience for responding to strangers asking a list of questions. The questionnaire was relatively short and limited to "yes" or "no" questions as much as possible.

28 Timidria, L'Association de Défense des Droits de L'Homme et de Développement (Association for the Defense of Human Rights and Development) works to improve the socio-economic situation of victims of slavery by reintegrating them into society. Timidria strives to preserve social peace and promote national unity and promote human rights in Niger. For more, see: Peace Insight, "Timidria, L'Association de Défense des Droits de L’Homme et de Développement," https://www.peaceinsight.org/conflicts/niger/peacebuilding-organisations/ timidria/.

29 For a history of Niger's democracy troubles up to the early 2000s, see: Leonardo Villalón and Rahmane Idrissa, "A Decade of Experimentation. Institutional Choices and Unstable Democracy in Niger," in The Fate of Africa Democratic Experiments. Elites and Institutions, eds. 


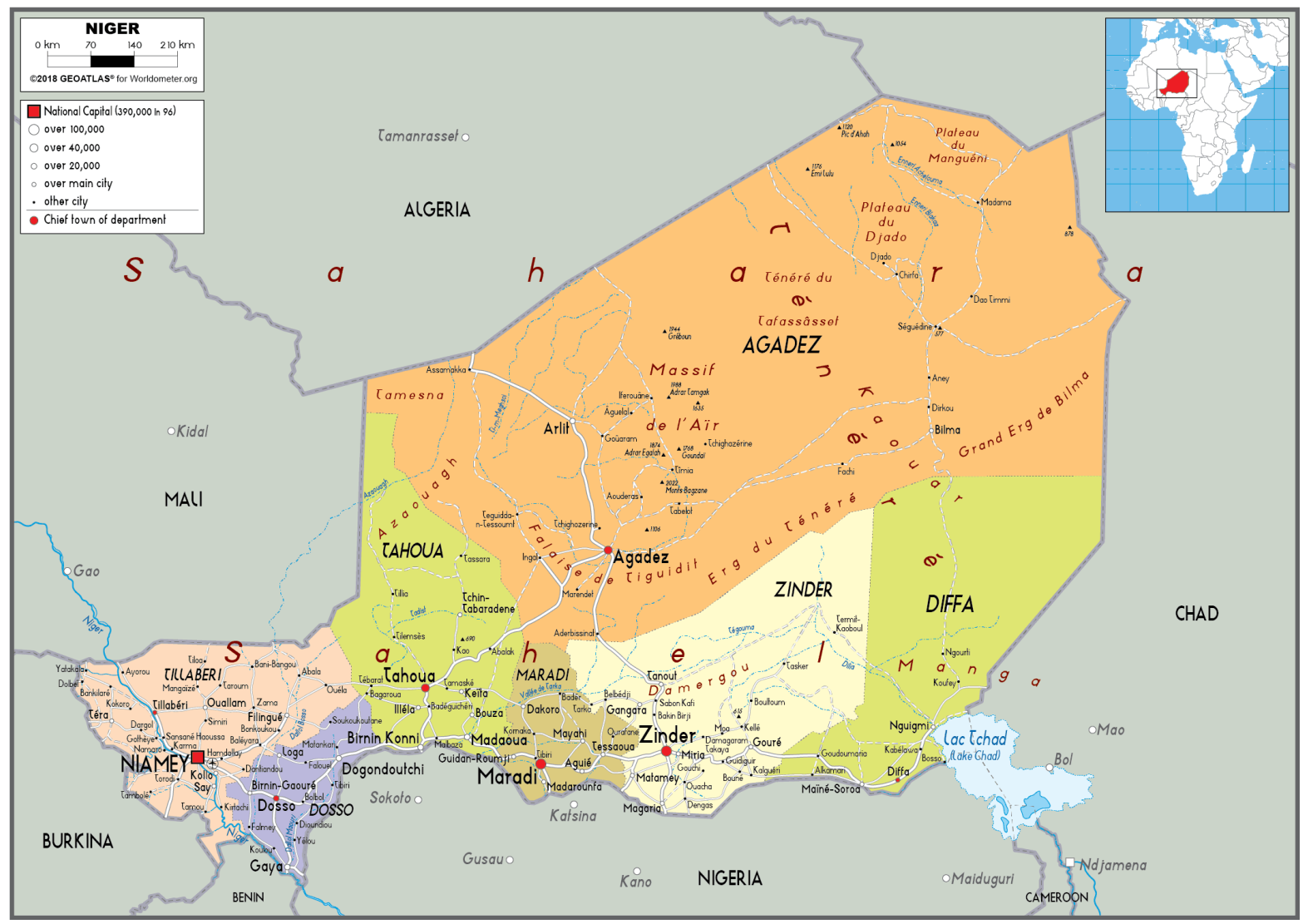

Figure 1: Administrative Map of Niger $^{30}$

The Niger-Mali border has a complex social setting with a turbulent history. Ecologically, the region is part of the agropastoral zone of transition from the Sahel to the Sahara. The farming populations are Songhay in Ayorou, Zarma in Bani-Bangou, and Hausa in Abala. These three localities were chosen for the study because they are the administrative centers of the three districts that are most exposed to the conflicts that have their epicenter in nearby northern and central Mali. However, Bani-Bangou, which sits practically on the border with northern Mali, is so exposed to violence that fieldwork was not feasible.

Ayorou is an old settlement. It served as a retreat to the fleeing Songhay emperor Sonni Baru after his general Askia Muhammad removed him from power in 1493 and took over the Songhay state. Bani-Bangou and Abala are more recent settlements, both born of the 1930s colonial regime's project to expand landed agriculture. ${ }^{31}$ Bani-Bangou means "the good pond" in Zarma, while Abala comes from a Tuareg way of saying "bubbling out" (of water), signifying the aquifers that farmers found favorable to agriculture in a dry environment. The two settlements became anchor points for the teritorial government, which provided the safety and amenities needed for a market. The settlements attracted satellite com-

Leonardo Villalón and Peter VonDoepp (Bloomington and Indianapolis: Indiana University Press, 2005), 27-48.

30 Political map of Niger, Worldometer, https://www.worldometers.info/maps/niger-political-map/.

31 M. O. Ijere, "Colonial Policy in Nigerian Agriculture and Its Implementation," Agricultural History 48, no. 2 (1974): 298-304, http://www.jstor.org/ stable/3741237. 
munities that were often, though not exclusively, settled by the pastoral transhumant communities, ${ }^{32}$ the Tuareg and the Fulani. ${ }^{33}$

In 1964, four years after the country became independent from France, both Abala and Bani-Bangou rose to the status of administrative post (poste administratif), the lowest rung of the country's territorial administration. By 2011, they had both become départements, the second highest rung. In their state-supported drive to colonize land, the farming communities also installed community leaderships that would administer land use and ownership through customary rules. These leaders - village chiefs, at the least ${ }^{34}$ - were integrated into state administration under the Ministry of the Interior and thus became the first mechanism for ensuring balance between the various communities in the districts. This integration was initially only semi-formal, until reforms in the early 2010s made traditional chiefs into formal agents of the territorial administration. ${ }^{35}$

Administration by way of traditional chiefs has been used to cope with the tensions that rapidly became apparent across the border region. Before colonialism, which started in Niger in 1899, the area was under the hegemony of Tuareg groups who had moved in during the late 18th and early 19th centuries and subjected farming communities to levies under the threat of violence. But in the colonial era and after, the central state became the agent of land colonization. A state hungry for taxes backed Zarma and Hausa land colonization for farming during colonialism and the First Republic (1960-74), while it was fixated on agricultural yields under the "food self-sufficiency" policy of the military regime (1974-91). ${ }^{36}$

To ease the tensions and conflicts that brewed in this process, the state intended to integrate traditional rulers from the pastoral groups in addition to farming community leadership structures. In this balancing act, the territories became an intricate web of canton and village chieftaincies (leaderships of the farming groups) enmeshed with groupement and tribu chieftaincies (leaderships of the pastoral groups), each with varying claims over different stretches of land and bases of legitimacy. These leaderships work in close collaboration with the local representatives of the territorial administration, the préfets, to defuse or manage conflicts.

32 In Niger, where large-scale transhumance is practiced, sedentary livestock farmers develop localized strategies to move their herds between pastoral enclaves, whereas transhumant herders are driving their herds longer distances over the years. See: Food and Agriculture Organization of the United Nations (FAO), "Information system on pastoralism in the Sahel: Atlas of trends in pastoral systems in the Sahel 1970-2012," 2012, http://www.fao.org/3/i2601e/i2601e.pdf.

33 E. K. Hahonou, Les Pouvoirs locaux à Balleyara (Niamey: LASDEL, 2002); Hamani Oumarou, La Construction du 'local' et la gouvernance communale par le bas. L'exemple de la commune rurale de Banibangou (Niger) (Niamey: LASDEL, 2011).

34 Village chiefs are part of leadership structures that also include Muslim clerics and sometimes the heads of traditional worship.

35 Mahaman Tidjani Alou, La Chefferie au Niger et ses transformations (Niamey: LASDEL, 2009); Fransje Molenaar et al., The Status Quo Defied: The Legitimacy of Traditional Authorities in Areas of Limited Statehood in Mali, Niger and Libya (The Hague: Clingendael Institute, 2019), https://www.clingendael.org/pub/2019/legitimacy traditional authorities mali niger libya/.

36 Fransje Molenaar et al., "The historical trajectory of traditional authority structures in Mali, Niger and Libya," in The Status Quo Defied: The Legitimacy of Traditional Authorities in Areas of Limited Statehood in Mali, Niger and Libya, eds. Fransje Molenaar et al. (The Hague: Clingendael Institute, 2019), 26-52, https://www.clingendael.org/pub/2019/legitimacy traditional authorities mali niger libya/2-the-historical-trajectory-of-traditional-authority-structures-in-mali-niger-and-libya/. 


\section{Corridors of Conflict}

Deadly violence flares at times and remains an issue for the entire agropastoral area of Niger where space sharing between farming and herding is highly contentious. By the early 2010s, there were officially 943 transit corridors and pathways for pastoral cattle transhumance across the national territory. ${ }^{37}$ Farmers do not accept the legitimacy of many of these routes, and state enforcement is weak or absent, especially as it would often depend on collaboration from local chiefs across ethnic groups. As a result, these routes sometimes turn into conflicts between armed men in the community. ${ }^{38}$

Before 1991, violence was limited, albeit not absent, and peaceful modes of conflict resolution prevailed. Retrospectively, the period, though not without its problems, is seen as a golden age by actors as different as traditional chiefs and Fulani militiamen. In the 1990s, the transition to democracy reshaped Nigerien politics. A series of governmental crises (including two coups d'état in 1996 and 1999) and submission to the demands of donors (such as the World Bank, the International Monetary Fund, and other development aid agencies) for austerity and privatization resulted in a general weakening of state authority. ${ }^{39}$

At the structural level, weak enforcement of the transhumance corridors by the territorial administration was also due to farming's expanding frontier as a result of population growth (particularly among farming or settled communities), extensive agriculture, and the failure of the policies aimed at transforming farming practices to manage resources equitably. Moreover, successive Nigerien governments have tended to treat pastoralism as a lesser sector in their rural development efforts, despite the central importance of livestock both in the domestic economy and for exports. ${ }^{40}$

For half of the 1990s, Tuareg groups rebelled on both sides of the Mali-Niger border, attacking the penurious state(s). In this parlous context, a violent rivalry grew between Fulani and Tuareg (Daoussahak) herders across the border in the later years of the decade. Both Nigerien and Malian governments neglected this conflict, seeing the Tuareg rebellions a more urgent and important matter, even as residents of the border region experienced the local violence as an epiphenomenon of those rebellions.

Zakary Rhissa, Revue du secteur de l'élevage au Niger, FAO/SFW, 2010, https://reca-niger.org/IMG/pdf/Niger Revue national.pdf.

Community-based armed groups are entities embedded in communal structures that can be based on territorial or ethnic affiliations that contribute to order and disorder through exercise of structural, normative, or outright physical violence. In this case, the presence of arms in a community and use of those arms in limited reprisals is not enough to suggest a level of organization and chain of command to consider these conflicts between CBAGs. See: Van Metre, From Self-Defense to Vigilantism.

39 Abdoul W. Barry, B. Lynn Salinger, and Selina Pandolfi, "Sahelian West Africa: Impact of Structural Adjustment Programs on Agricultural Competitiveness and Regional Trade," African Economic Policy Discussion Paper Number 37, December 2000, http://hubrural.org/IMG/ pdf/usaid impact structural adjustments on ag competitiviness.pdf.

40 Livestock is recurrently Niger's second or third export commodity after uranium and the key cash crop of the day (groundnuts in the 1960s, onion today). See: Claude Raynaut and Souleymane Abba, "Trente ans d'indépendances: repères et tendances," Politique Africaine, 38 (June 1990): 3, https://f-origin.hypotheses.org/wp-content/blogs.dir/1629/files/2020/05/038003.pdf; Clara Jamart, "Niger's Rural Code and the Pastoralist Issue," AGTER, March 2011, https://www.agter.org/bdf/en/corpus chemin/fiche-chemin-91.html. 
After the rebellions ended (1996-98), the herders' intercommunal conflict was taken more seriously by state actors. Pastoralist groups had mobilized men into armed ethnic militia and created a dangerous demand for firearms. ${ }^{41}$ In 1999, and again in the late $2000 \mathrm{~s}$, state authorities, especially in Niger, organized peace-brokering and de-escalation forums between the competing ethnic groups. Although these forums resulted in general agreements, they suffered in enforcement each time.

In the 2000s, across Niger local elected authorities emerged as a result of a decentralization process of state governance administration. In Niger's democratic scheme, these new authorities were thenceforth the only local political leaders (in theory), given that traditional authorities occupy a segment of the territorial administration, which is a service, not a political organization. But this apolitical concept of traditional authorities has always been fiction. To affirm their power and keep their privileges, traditional chiefs garner political legitimacy derived from the sociocultural authority of customs, traditions, and blood inheritance. This claim of representing and ruling local communities via tradition conflicts with the elected local officials' claim of doing the same via democracy.

Traditional chiefs ultimately owe their position to state sanction, since the state can sack them at will, but they also form a powerful interest group that has managed to keep control over the crucial issues of land ownership and exploitation. ${ }^{42}$ To preserve this position, traditional chiefs must compete for influence with elected officials. At another level, they are vulnerable to manipulation from the central government and powerful politicians in the capital. Dependence on the state, the need to preserve their class interests, competition with elected officials, and manipulation from the center all combine to create political problems that call into question the value of chiefs as an institutional mechanism for keeping the balance of peace in rural Niger. ${ }^{43}$

In August 2013, when violence engulfed the neighboring regions of Mali to the north, a forum was convened at Bani-Bangou by a non-governmental organization, the Nigerien Network for the Non-Violent Management of Conflicts. ${ }^{44}$ The organization took stock of the various unresolved issues contributing to violence escalation. The conventional drivers of tolerable sources of violence (within context of limited historical reprisals) and the main grievances of farmers and herders were duly pinpointed. So were newer and more ominous issues, e.g. the increasing prevalence of firearms and drug consumption. Moreover,

41 Until the collapse of Libya and resumption of the Tuareg rebellion in Northern Mali, availability of weapons was largely limited to small and light weapons. Prevalence of heavy military armaments have subsequently contributed to the escalation of violence and operational capacity of armed groups.

42 Christian Lund, "Precarious democratization and local dynamics in Niger: micro-politics in Zinder," Development and Change 32, no. 5 (2001): 845-69, https://doi.org/10.1111/1467-7660.00229.

43 Abdoulaye Mohamadou, "Foncier, pouvoirs locaux et décentralisation dans le département de Dakoro (Niger)," Bulletin de l'APAD, 31 -32 (2010): 105-136, https://doi.org/10.4000/apad.4052; Idrissa, "Traditional authorities in Niger: Politicization and under-representation."

44 Réseau nigérien pour la gestion non violente des conflits (RE-GENOVICO), Niger. See: https://www.ndi.org/our-stories/ supporting-stability-and-countering-extremism-sahel-region-africa. 
camps of Malian refugees were seen by many as harboring potential bad actors. ${ }^{45}$ In other agropastoral regions of Niger, where the clashing grievances of farmers and herders were no less serious, these three new elements were almost (arms and drugs) or totally (Malian refugee camps) absent elsewhere. But by the time of the forum, the violence it wished to prevent was already becoming endemic, and the precarious balance faltered.

\section{Agents of conflict: armed actors and (once limited) violence}

Assessing the extent of armed group activity and violence is a challenge due to the volatility of the region. Actors are multiple, their agendas differ, and their actions contribute to a degree of confusion that complicates any strategy of peace restoration. Major actors include

- community-based armed-groups (CBAGs) of Fulani and Tuareg ethnicity;

- Salafist armed groups led in many cases by outsiders (especially from North Africa) but attracting people from all resident communities in the Sahel-Sahara;

- criminals, outlaws, and marauders, including drug traffickers, arm smugglers, and cattle thieves, some of which may enjoy complicities both in the governments of Mali and Niger and with the Salafist armed groups; and,

- Western militaries and intervention missions, chiefly French and United Nations, with support from the US and other western powers.

- Some violence is non-state, though not anti-state (e.g. drug traffickers); some other violence is clearly anti-state, but not necessarily for the same reasons (e.g. Salafists, communalists). Divergent histories behind the violence depend on the national context, which, however, does not preclude some contamination effect.

Since 2013, violence has become endemic in the Niger-Mali border region in two ways. First, armed violent extremists target state security and governance actors and those perceived as its allies, especially local traditional chiefs. Violent extremist groups also engage in deadly punitive violence against those who refuse to follow their rules, including tax payments, and attempts to transform the local political order. Second, violent crime markedly increased in the form of armed cattle robbery and forcible removal of people from isolated camps and hamlets (sometimes resulting in fatalities), as opportunistic score-settling over access to natural resources and the political power that comes with land possession.

45 Niger24.org, "Forum de Banibangou: Prévenir et gérer les conflits grâce au dialogue intercommunautaire," Niamey.com, August 14, 2013, http://news.aniamey.com/h/3757.html. 
Although the balance in the region had become precarious by the early 2010s, it may not have collapsed without the Tuareg insurgent groups formed against the Malian government, the National Movement for the Liberation of Azawad (MNLA in the French acronym), and jihadist wars of northern Mali. ${ }^{46}$ These wars brought into the border region new patterns of violence that led to a sense of confusion, the "psychosis" described in the findings section. Armed community mobilization from marginalized ethnic groupings consigned to the lower rungs of traditional social hierarchy is a new phenomenon, and in part explains the events described by one interviewee as "chiefs hunting" ("chasse aux chefs"): the killing of traditional chiefs. ${ }^{47}$ Once negotiated and limited reprisal-based violent events evolved into a coercive, unbounded effort to eliminate interdependent socioeconomic collaborators. Community-based armed groups in Niger thus must be considered symptomatic of the unraveling of the hybrid political order, ${ }^{48}$ rather than a fixed actor as present in other Sahelian locales.

Armed violence in the name of jihad is also new, ${ }^{49}$ although it often follows old patterns and familiar tactics, such as seizing people's cattle under pain of death and calling that a tax-this time zakkat (the Islamic tax) rather than jangal (a Fulani word for cattle tax). ${ }^{50}$ New actors mobilize people with old grievances, using an ideological discourse that mixes Salafist rigorism with more traditional Islamic social criticism. Most who join in are young Fulani and "Black" Tuareg, but people from other communities, including the farming ones, are also attracted, if in much smaller numbers according to local observation or perceptions of interviewees. Moreover, opportunistic, marauding violence grows due to the increased availability of firearms, leading to more cattle theft and lawlessness. This creates conditions of disorder and anomie in which it is difficult to build a consistent policy response.

46 Stewart, "Mali Besieged by Fighters Fleeing Libya."

47 Radio France Internationale, "Niger: les jihadistes ciblent les chefs de village," November 24, 2019, http://www.rfi.fr/fr/ afrique/20191124-niger-jihadistes-chefs-villages.

48 Bethany McGann, "Hybridity and Fragmentation: Implications for Regional Security Policy in the Sahel and Beyond," in Extremisms in Africa Volume 3, eds. Stephen Buchanan-Clarke et al. (284-313. Good Governance Africa, 2020), 284-313.

49 Prior conflicts were not predicated on a religious basis and rather used religious norms or practices to litigate resolution and reconciliation measures. See: Yvan Guichaoua, "Mali-Niger: une frontière entre conflits communautaires, rebellion et djihad," Le Monde, June 20, 2016, https://www.lemonde.fr/afrique/article/2016/06/20/mali-niger-une-frontiere-entre-conflits-communautaires-rebellion-etdjihad 4954085 3212.html.

50 Zakkat is a religious obligation ordering Muslims who meet the necessary criteria to donate a certain portion of wealth each year to charitable causes. The reversal of terminology might speak to tightening bonds between Tuareg and militant Islamist groups versus collective relations based on land use and belonging. 


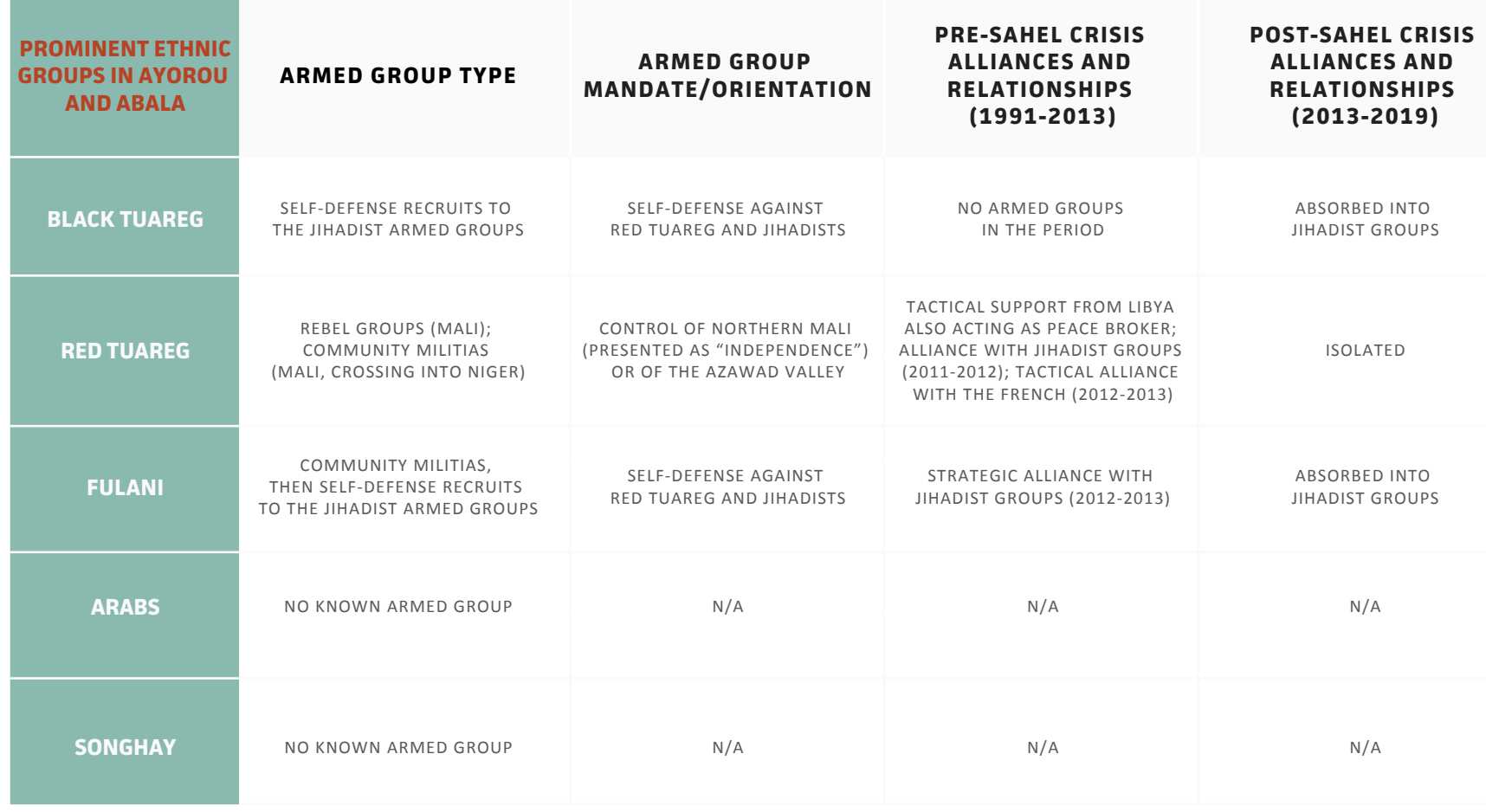

Table 1. Armed Groups and Ethnic Affiliations in Niger

In assessing the nature of the violent armed actors engaged in both anti-state and intercommunal violence, Van Metre's typology of community-based armed groups and the ways in which they exercise violence is a useful tool to both understand the function of armed community mobilization in Niger. ${ }^{51}$ It also helps analyze how the breaking of intercommunal balancing mechanisms has contributed to the pervasive sense of "psychosis" (discussed in the findings) and escalation of retributory acts. The presence of traditional chiefs and their role in conflict resolution created constraints on the extent of violence and the levels of violence that would trigger escalation versus resolution. As a result, most, if not all, intercommunal violence was negotiated (before the breakdown in the Sahelian security environment) and within socially tolerable norms around violence. The trajectory of armed mobilization by communities was thus doubly constrained by the negotiated relationship of the chiefs with the state, rendering them in a similarly negotiated position with state security forces.

The role of traditional chiefs as interlocutor is important for jihadist or other militant groups encroaching on Nigerien territory or traversing the hundreds of trade corridors. Where some chiefs were murdered for non-compliance, others enter into negotiated relationships with the armed actors for numerous and rational reasons. ${ }^{52}$ They may have sought protection of the community or from other jihadist groups or

51 The framework explores links between the external operational environment of armed groups and their internal functions, especially their exercise of violence, linking CBAG organization and operation to environmental factors and CBAG transformations to shifts in these factors. The typology helps analyze a CBAG at a given point in light of its external and internal characteristics to identify potential points of leverage to engage, manage, or transform it. Van Metre, From Self-Defense to Vigilantism, 14-24.

52 International Crisis Group, "Sidelining the Islamic State in Niger's Tillabery." 
realized that if violent extremists hold territory and establish order, they would maintain intercommunal balancing mechanisms through that order-a third party role once held by the state. Absent the chiefs as a primary point of negotiation, the political and physical distance between communities and state security actors and security policy dissolved the negotiated status that prevented or reduced anti-state violence and broad intercommunal conflict. The relationships between communities and jihadist, militant, and criminal forces can be interpreted as a coercive hostage taking, where the mutual benefits are quickly overtaken by leveraging communities via recruitment or propaganda to reinforce jihadist operational capabilities and perceived legitimacy as a governance alternative.

While tensions over natural resources (land, cattle, and demarcation between agricultural and pastoral areas) are factors of frustration that may lead to violence and conflict perpetrated by ethnically aligned groups, economic interdependence is a factor of moderation that historically facilitated non-violent resolution of tensions. However, a non-violent outcome depends to a decisive extent on initiatives and policies at the state level-like the decision to integrate chiefs into the formal state architecture led to a reduction in the pre-2012 violent contestation. The latest peace restoration meeting, arranged by Niger's prime minister Brigi Rafini in 2011, with disarmament attempts failed due to under-enforcement, as it was brokered just before war-first intrastate, then jihadist-driven-broke out in northern Mali. ${ }^{53}$

\section{FINDINGS}

If economic interdependence reduces outbreaks of extreme violence in the entire agropastoral zone of Niger, it is complicated in specific regions by sociopolitical issues. The following section discusses the findings from the surveyed populations in Ayorou and Abala, which revealed two main factors characterizing the collapse of moderating forces, and thus the expansion of violence, in Niger's border regions: (1) a pervasive state of violence and mistrust, and (2) intra-ethnic competition over formal and informal governance systems.

\section{Violence and mistrust}

The first and most notable finding from the research carried out in Ayorou and Abala in 2019 was the extent of confusion, fear, and pessimism that local communities expressed when asked about the state of violence. The dominant mood about the state of violence based on the interviews can be summarized by three patterns: psychosis, mistrust, and hope.

\section{PSYCHOSIS}

The word "psychosis" (French psychose) has become a locally developed shorthand for describing the public response to the climate of violence in the region. A popular version of the word signifies generalized fear, a feeling of insecurity, of being threatened in the fog. In Bani-Bangou, where the psychosis is

53 Idrissa, "Traditional authorities in Niger: Politicization and under-representation," 70-73. 
arguably the highest, even bona fide researchers in possession of the necessary research documentation are viewed with suspicion as outsiders and thus potential attackers. This is in part a product of the fact that no one can clearly discern where the attacks come from, who the perpetrators are, or why they carry them out. ${ }^{54}$

In previous episodes of violence, notably in the 1970s and 1980s, it was reasonably clear to violence-affected communities who had attacked whom, why, and when. For example, oral histories exist about local squabbles, often recounted by interviewees going back to the $1970 \mathrm{~s} .{ }^{55}$ According to these accounts, previous episodes of violence were mostly due to violence by farmers defending their fields and gardens from the depredations of herders' cattle; herders defending their access to pasturelands; and groups from different-and sometimes the same-communities fighting over respective claims of land. A pattern of more gratuitous violence came from Tuareg groups raiding cattle belonging to members of all non-Tuareg communities. The awareness of patterns around the violence occurring in the area, which resulted from traditional tribal chiefs moderating confrontations and establishing norms of violence, has since evaporated. ${ }^{56}$

Current iterations of violence were noted as more mystifying by interviewees for this report in northern Tillabéry. One interviewee used the word "mystification" for what he considered an intentional effort to sow confusion, characterized by perpetrators who disguise themselves in Fulani clothing or speak Fulfulde (the language of the Fulani) to portend that they are Fulani when in reality they are not. ${ }^{57}$

\section{MISTRUST}

Psychosis breeds all-out mistrust. The issue of the lack of trust recurred in all the interviews. To some extent interviewees correlate the rise of mistrust with the arrival of outsider ${ }^{58}$ - not only refugees from Mali ("people we do not know"59) but also itinerant Arab traders who are based in Mali and may be seen as sharing in the same culture as the Arabic-speaking North African leaders of jihadism. But the mistrust is generalized and shows no clear pattern. "There are too many unanswered questions," said a villager. ${ }^{60}$

A byproduct of the psychosis is the self-imposed restriction of movement among community members. In Ayorou, the local head of a human rights defense organization explained that while communities experience mass flight, attackers seem to enjoy great freedom of action unbound by concerns about mobil-

54 This information came from strong advice from other researchers not to go to Bani Bangou. A month before our fieldwork, a team from the Niamey-based social science laboratory LASDEL — the institute that hosts EPGA, a think tank in political economy in Niger founded by the author, Dr. Idrissa-cut short a fieldwork in Bani Bangou after authorities there warned them that their safety and security could not be guaranteed.

55 Perhaps due to the traumatic times of the Great Sahel Drought in 1968-1985.

56 Focus groups in Niamey after the fieldwork, 2019.

57 Interview with local government official (1) of Ayorou, 2019.

58 Interviews with local government official (1) and local government official (2) of Ayorou, 2019.

59 Interview with local government official (1) of Ayorou, 2019.

60 Interview with a local villager from Ayorou, 2019. 
ity and security and undeterred by the enhanced presence of security actors that limit mobility. ${ }^{61}$ This contrast contributes to a climate of mistrust between communities and also between community and state. If people cannot know where and when attackers will strike, they move about as little possible. As one interviewee vividly indicated: "Before, in the 1980s, herders would march up to Tasara [over $400 \mathrm{~km}$ away] to give water to their cattle in the dead of the night. Today, one hesitates to go to Firgoun in broad daylight, even though it is only $8 \mathrm{~km}$ distant. ${ }^{62 \prime \prime}$

Many are convinced that "the bandits" (the word used in the region, rather than "terrorists," which is current in the capital ${ }^{63}$ ) have spies and accomplices in the central government itself. Absent protection for and by traditional chiefs, suspicion of the state is a rational outcome of the disruption in locally derived logics of normative violence and conflict resolution due to terrorist actors and counterterrorism efforts alike.

\section{HOPE}

There is a clear contrast between Ayorou and Abala. The pessimistic interview responses that stressed psychosis and mistrust were overwhelmingly from respondents in Ayorou. Respondents in Abala also presented a gloomy picture of the situation but they were comparatively more hopeful for the future. Their hopefulness came mainly from satisfaction that the exchange economy was restarting, giving credit to political initiatives from both the deputy mayor of Abala and the central government (e.g. the High Authority for Peace Consolidation, HACP in the French acronym). ${ }^{64}$ The exchange economy, as embodied in the market at Abala, is the pragmatic mechanism undergirding interdependence. ${ }^{65}$

In Abala, we met a representative of the Movement for the Safety of Azawad (MSA) ${ }^{66}$, a Malian Tuareg separatist group. He was a cattle trader who had come for business and insisted on the friendship between Tuareg Daoussahak and Fulani (the two main antagonists in the local armed conflict), even as he recognized that just a few months before he would not have felt safe coming to the market. All interviewees insisted that more needed to be done to prevent the crisis from waxing again. The work of HACP in particular was praised. The institution appears to have a working early warning system in the area, which helped to prevent a number of inter-community brawls. This system grew out of the relationships that

61 Interview with senior official at the Nigerien Association for Human Rights Defense (ANDDH) in Ayorou, 2019.

62 Interview with local government official (1) of Ayorou, 2019.

63 The state adopted the language of counter terrorism in its military action against the cross-border militant Salafist threat. Denoting these individuals as "terrorists" trades in the common discourse of othering those responsible for violence as "not Nigerien."

64 According to its official mission, placed under the supervision of the Nigerien presidency, HACP is responsible for cultivating peace, dialogue, and respect, and identifying solutions to the socioeconomic causes of insecurity, banditry, rebellion, and new sources of insecurity linked to terrorism and trafficking. It develops, implements, and monitors recovery programs for conflict-affected communities and works to identify actions to correct inequality, disparity, and exclusion in the development process, to promote national cohesion and unity. For more, see: "Mission de la HACP," Haute Autorité à la Consolidation de la Paix (HACP), accessed March 25, 2021, http://www. hacp-niger.org/.

65 Sites of intercommunal interaction have a positive impact on the reported psychosis, as regularized interactions between communities reduce the specter of other.

66 The group splintered from MNLA in September 2018. 
HACP built with local chiefs and clerics, which are more permanent and continuous than the ones supposed to exist between them and local and regional territorial administration (prefects and governors). In addition, HACP can generally establish more informal and unobtrusive contacts with local informants than other state organizations.

Peacebuilding, dialogue, respect, identifying solution to the socioeconomic causes of insecurity, banditry, and rebellion, and new sources of insecurity linked to terrorism and trafficking. Program implementation and data collection, identify actions to correct inequality, disparity, and exclusion in the development process, national cohesion and unity, validating impact on the communities concerned.

However, these initiatives and efforts do not seem to be capable of placating a key demographic: the radicalized youth of the Fulani herding communities. The Salafist message that organizes the anger of Fulani youth is also attractive to youths from other communities. However, young Fulani (and "Black" Tuareg) are believed to be the bulk of the violent extremist recruits, and they have remained impervious to the attractions of peaceful interdependence. This is small wonder, since their discontent stems in large part from the difficulties of integrating the pastoralist-farmer economic system in the region. According to two individuals from the region of Tahoua ${ }^{67}$ interviewed in the focus group held after the fieldwork, the initial cause of these difficulties in economic integration are the increasing restrictions to transhumance corridors due to security force operations and the lack of well-regulated demarcations between farmlands and pasturelands. ${ }^{68}$ Moreover, the population growth rate is much higher among farmers than among pastoralists, further limiting access to available land and driving grievances among mobile communities. ${ }^{69}$

\section{Interdependence and the state}

The social setting in the research area is complex. Across the two sites, there are five ethnic groups, the Songhay-Zarma and the Hausa, who are farming communities, and the Fulani, the Tuareg, and the Arabs, who are mainly pastoralists. All communities possess some cattle and other animals and have a trading caste. Among the Fulani and Tuareg, the divide between "masters" and "slaves" is stark, even though slavery is illegal in Niger. It is also racialized as the local language speaks of "Red" and "Black" Tuareg (also known as Bella, from a Songhay word) ${ }^{70}$, with the former being the purported masters, and the latter the purported slaves.

67 The administrative region of Niger east of Tillabéry.

68 Focus group held in Niamey after the fieldwork, 2019. Though this research was conducted in advance of the 2020 COVID-19 global pandemic, the impact of COVID-related border closures on pastoralists had similar effect to the increased security operations and scrutiny of transhumant communities.

69 Rahmane Idrissa, "Political Economy of Fertility in Rural Niger: Exploring the Communes of Karma and Aguié," Study report, Sahel Resilience Learning (SAREL) and USAID, 2016.

70 The concept of "Black Tuareg" (Touareg noir) seems to be preferred in public discourse by those who identify as such, and I will use it in the main in this paper. However, in local parlance in the local communities, the term Bella prevails, and I will use it in this section. These words are confusing also because the word Bella, which is a Songhay word, is often used by Songhay speakers for all Tuareg, "Black" and "Red," despite the fact that the Songhay language actually has a word (Surgu) for "Red" Tuareg. 


\begin{tabular}{|c|c|c|c|c|c|c|}
\hline Site & Arabs & Hausa & Fulani & Songhay-Zarma & Tuareg & Total \\
\hline Ayorou & 12 & 03 & 24 & 34 & 30 & 100 \\
\hline Abala & 07 & 23 & 27 & 20 & 23 & 100 \\
\hline Total & 19 & 26 & 50 & 51 & 53 & 200 \\
\hline
\end{tabular}

Table 2: In both research sites, Ayorou and Abala, members of all ethnic groups were surveyed.

The numbers that matter are those that distinguish communities with a pastoral and a farming heritage: 61 percent of respondents belong in pastoral, and 39 percent in farming groups. These proportions, though emerged randomly, and maybe precisely because of that, are indicative of the weight of the pastoral communities in the area. These communities are also the main actors in the state of violence. ${ }^{71}$ Interdependence was assessed by querying respondents about intermarriage (both between communities and within, in pastoral communities across the status divide), relations in the fields, relations on the market, and languages spoken. ${ }^{72}$

The patterns that emerged from the survey indicate that interdependence is strong between all communities, except the Tuareg and Fulani, and tends to be weak or fractured along the caste status divide within the pastoral communities. This is showcased in conflicts that oppose "masters" and "slaves" among the Tuareg and the Fulani. These terms mirror the French language words used in public discourse in Niger ("maîtres" and "esclaves") to reflect not actual slavery but forms of traditional subordinations originated in times when Tuareg, Fulani, and other local societies lived under a regime where various forms of servitude, including slavery, were practiced. ${ }^{73}$

Today, descendants of "masters" strive to preserve some of the rights and authority that they derive from that ancient regime, whereas descendants of the subaltern and servile groups strive to resist this, leading to tensions that may erupt into conflicts under certain conditions. These conflicts showcase failing interdependence breeding conflict dynamics that drive radicalization, as groups increasingly interact and intersect with militant forces operating in the area in agitation against the state's failure to manage contestation. The narratives of the jihadist elements resonate with groups seeking to overcome historical caste interrelations.

71 The pastoralist communities are politically disadvantaged in the state-supported efforts to expand farming and therefore commodity production.

72 This survey attempted to gain a sense of what the interdependence between resident communities entail, as well as how the state is perceived. This single-site market-day survey is not a scientific poll. However, if its results capture common opinions in a snapshot, it is useful when contextualized. Since this is not measurement, this research will not use the numbers to analyze the survey but will instead refer to the patterns indicated when set against contexts.

73 For Benedetta Rossi's work in the neighboring Ader region, see: Bendetta Rossi, From Slavery to Aid. Politics, Labour, and Ecology in the Nigerien Sahel, 1800-2000 (Cambridge: Cambridge University Press, 2015). 
A prime example can be found in Inates, a Tuareg settlement in the department of Ayorou where the Nigerien army suffered a deadly attach in mid-December $2019 .{ }^{74}$ Inates has a chieftaincy held by high-status "Red" Tuareg. The majority of the local community are "Black" Tuareg (or Bella), who resent the domination tinged with condescension, racism, and violence of the "Reds." 75 The process of decentralization, which led to the emergence of local elected authorities (mayors and councilors) in the 2000s, saw the rise in power of Bella officials through the vote. Inates became a site where traditional power and democratic legitimacy clashed along the status line: while the chief is still a "Red" Tuareg, the mayor is a Bella. While the cause of the Bella is buoyed by democratic participation, the cause of the "Red" appears to be supported by the state, since chiefs are members of the territorial administration and derive power and influence from that position, allowing them to curtail the progress of local democracy.

In the current climate of violence, two chiefs of Inates-a father and a son-were murdered successively (in April and July 2019). The entire cattle of the mayor (over 800 heads)-and in this context cattle are capital-was stolen by an armed band at the cost of several fatalities. These events signal that the fight between "Reds" and Bella has turned deadly. Inates has since become a recruiting ground for violent extremist actors, with many individuals receptive to the radical criticism against traditional forms of domination, which are seen as vetted by the state. In this area, HACP, perceived to be "on the side of the chiefs (and "masters"),"76 is not welcome and performs much less well than in Abala, for instance.

In Inates, there is an economic interdependence between Bella and "Red" Tuaregs, but the case suggests that interdependence leads to moderation when it is based on equality, not on a culture of inequality. ${ }^{77}$ In the case of intercommunal relations in the fields and at the market with pragmatic exchange-based equality, the general pattern is also strong interdependence. This is marked at one end of a spectrum by the Hausa, the population that seem to have most positive relations with all communities, and on the other the Fulani, the population with least positive relations with all communities.

The case of the Hausa may be explained by certain aspects of their community, including stronger engagement in trade and services and less status hierarchy in their society (though it is hierarchical in a different way) and less taboos than others. Unlike the Songhay-Zarma, the other farming community in the region, the Hausa practice the trade of the butcher and meat seller, for instance, an important trade with cross-cutting economic relationships in an agropastoral region.

74 Hannah Armstrong, "Behind the Jihadist Attack in Niger's Inates," International Crisis Group, December 13, 2019, https://www.crisisgroup.org/africa/sahel/niger/behind-jihadist-attack-inates.

75 In an interview, an elected official of Inates, a "Black" Tuareg, said of the "Reds": "These are people who used to kill and plunder as they liked and did not think that the same could happen to them." The record of this violence belongs in oral history and has not been researched by academics or journalists. It is thus unverified but not unbelievable.

77 Elites, in this culture, believe that slavery is God-ordained. When a French airstrike killed "Black" Tuareg insurgents, they saw in that event not the result of an "anti-terrorist action," as the French thought it was, but God's punishment for the "slaves' treason." (Interview with local government official of Inates, 2019.) 
The case of the Fulani may point to two divergent elements of explanation. On the one hand, it might mean that the Fulani are marginalized, which would then contribute to their radicalization. On the other hand, it might mean that the perception that they are the main perpetrators of violence in the region today has led to their greater marginalization and therefore greater willingness to form alliances with militants that do not perceive them as a sociopolitical adversary. The Fulani seem to have the poorest relations with the Tuareg, especially the "Red" Tuareg. Yet, interview data also indicate that in some of the violence groups of Fulani are allied with groups of Tuareg, including Daoussahak. ${ }^{78}$

The Fulani in this area are not a homogeneous group, despite their generalization in political discourse and regional security policy. ${ }^{79}$ They are divided in several communities named after the places of origin they claim and that are sometimes far from the border region. For instance, the Gandakobé Jaalgobé hail from the district of Téra, at the Burkina Faso border, over a hundred kilometers westward; the Adrawa Gorgabé from Ader, a region several hundreds of kilometers to the east; the Doubankobé Gobirankobé from Gobir, even farther than Adar, south-eastward. ${ }^{80}$ These groups do not see eye to eye with each other on all issues and may have different interests and alliances with other communities. The group seen as most committed to violent extremism, the Tolébé, attack other Fulani groups to forcibly levy a zakkat, the Islamic impost. ${ }^{81}$

The contrast between Ayorou and Abala bears out the hypothesis that weak or fractured interdependence creates less moderation and higher risks of violence. This is also shaped by perceptions of the economy and of the state, i.e. the power that may offset the risks by developing and implementing helpful policies-especially around resource governance. On both scores, the contrast between the two sites remains. To the question whether the economy was going well in their districts, Abala's respondents were much more sanguine than Ayorou's.

\begin{tabular}{|c|c|c|c|}
\hline State of the Economy & Ayorou & Abala & Total \\
\hline Rather Good & 12 & 49 & 61 \\
\hline Rather Bad & 79 & 39 & 118 \\
\hline No response & 9 & 12 & 21 \\
\hline Total & 100 & 100 & 200 \\
\hline
\end{tabular}

Table 3: Responses to the question whether the economy is going well in the district, by research site.

Most respondents in Ayorou (above 80 percent) are dissatisfied with government work in Education, Health, and Justice, whereas in Abala most (around 60 percent) are satisfied. In Ayorou, respondents complained most about Justice (43 percent), whereas in Abala about Education (40 percent). These two

78 The researcher was not able to disentangle this situation for want of the right research tools and time. This appears to relate to the overall complexities of the Fulani population in the region.

79 Madeline Vellturo, "Fulani and Jihad in West Africa: a complex relationship," Good Governance Africa, October 13, 2020, https://gga.org/ fulani-and-jihad-in-west-africa-a-complex-relationship/.

80 Several other groups of Fulani call Niger home. This list is not exhaustive, but relevant to the research sites and direct conflict dynamics.

81 According to one interviewee, in local capital, i.e. animals, this amounts to one bull, one two-year old male calf, and two rams. 
sectors strongly correlate with closeness to the state: education fosters state personnel, while justice is the key sector where state intervention is needed to sort out the conflict-nurturing issues. In Niger, the state speaks French, thus a career in state organizations requires school education in French. Therefore, this type of education is strongly associated with the state. A well-functioning justice system-especially according to local criteria-is the frontline prevention for conflict escalation. ${ }^{82}$

On the question of state/public governance, the governor ranks lowest, perhaps predictably as a more remote authority. Imams rank highest in Ayorou, and village chiefs in Abala. A telling contrast is the one about the gendarmerie, the central figure of the security state in the countryside and in small towns, which is significantly more appreciated in Abala (22 positive responses) than in Ayorou ( 8 positive responses). Mayors and the HACP also fare comparatively well. Overall, as of the time of this research no authority has reached a rate of positive responses of 50 (the highest rate, with 33 positive responses, was for imams in Ayorou). This suggests that there is more frustration than satisfaction regarding state/ public governance.

These numbers are not conclusive. They are reflective of a reality that is not limited to this part of Niger and that gains special salience only due to the conflicts that rage here. Large-scale surveys conducted by Afrobarometer record similar rates of frustration and satisfaction with government work across the country, though much lower feelings and incidence of physical insecurity. ${ }^{83}$ In that regard, the differences between Ayorou and Abala are consistent enough-and also consistent with interview data - to warrant a conclusion that policies from the state and local authorities can have a positive impact. But to understand the conditions and meaning of any positive change, we need to take a broader view, revisiting the concept of balance and diving into the historical interethnic relations beneath the surface of the state.

\section{REVISITING BALANCE: HISTORICAL AND POLITICAL TRENDLINES}

In the broader view, balance in the relations between the resident communities has long been limited by tensions and conflicts that reach deep in history and were precipitated by the political changes around democratization and decentralization in the 1990s-2000s. However, even these changes would not have led to the current conflicts without the war in Mali. Given the salience of these changes in local perceptions, the author has reconstructed them in this section by revisiting the relevant episodes in Niger's colonial and recent history.

82 See previous RESOLVE research report on dynamics in Chad related to language and secularism. Remadji Hoinathy and Daniel Eizenga, The State of Secularism in Chadian Higher Education: Testing Perceived Ties to Violent Extremism (Washington, D.C.: RESOLVE Network, 2019), https://doi.org/10.37805/lcb2019.2.

83 Afrobarometer, "Résumé des résultats. Sixième série de l'enquête Afrobaromtère au Niger, 2015," LASDEL, April 2015, http://afrobarometer.org/sites/default/files/publications/Summary\%20of\%20results/ngr-r6-sor.pdf. 
Change in the border area occurred in two great waves. The first wave dates back to the colonial era, the second to the 1990s (see next subsection). A romantic view of African history often faults artificial colonial borders for tensions and conflicts on the continent. This is assuming that what went on before was devoid of conflicts, a thinking that leads dangerously close to the racist notion that Africa had no history before the arrival of the White man. History is conflicts and struggles.

Colonialism broke a unified system that stretched from south of Timbuktu to the districts of Ayorou, Abala, and Bani-Bangou, down to areas just south of these towns, across the current border between Mali and Niger. This was the hegemony of the Tuareg Williminden nobility that developed in the late 18th and early 19th century. The Williminden hegemony did not build a state-it had no administration and did not render the services expected from a state-but rather provided a protection racket, enforced thanks to the warlike mobility of the Tuareg elite, cowing farmers for tributes. ${ }^{84}$ The first French military explorer of the region, Émile Hourst, was impressed and called the area "Tuareg country" ("pays des Touareg"). The first French book on the colony of Niger, also written by an army man, presented the main farming people of the area, the Songhay, as deserving to be run roughshod over. ${ }^{85}$

However, French colonialism needed labor and taxes, which were more forthcoming from farmers than from roving warlords. The power of the latter was therefore broken, and in the 1930s the farming communities started to expand northward. This is the period when the Zarma founded Bani-Bangou, and the Hausa founded Abala. Many of the disputes about land ownership around Ayorou also run back to this period. Tuareg chiefs claim that land was given to them by the forefathers of the (Songhay) chiefs of Ayorou, who rebuke the claim by implying that the land was actually extorted and must be restored to its rightful owners. ${ }^{86}$

This first wave of change is at the root of much Tuareg violence, which without context looks gratuitous. Many in the Tuareg elite remember this period as a time when the French substituted the Tuareg protection racket for theirs and eventually elevated the "inferior races" of the Zarma and Hausa, who had been ordained to be slaves, to a position of command. This subversion of the "natural order" was intolerable in their eye. ${ }^{87}$

84 Jean-Pierre Olivier de Sardan, Les Sociétés songhay-zarma, Niger-Mali: chefs, guerriers, esclaves, paysans (Paris: Karthala, 1984); Bendetta Rossi, From Slavery to Aid. Politics, Labour, and Ecology in the Nigerien Sahel, 1800-2000 (Cambridge: Cambridge University Press, 2015).

85 Émile Hourst, La Mission Hourst sur le Niger et au pays des Touareg (Paris: Plon, 1898); Maurice Abadie, La Colonie du Niger. Afrique centrale (Paris: Société d'éditions géographiques, maritimes et colonials, 1927); Olivier de Sardan, Les Sociétés songhay-zarma, Niger-Mali.

86 See Xavier Bernier, "Les consequences des sécheresses récentes sur le développement agropastoral au nord de Filingué (Niger)," (Thesis, Université Joseph Fourie, Grenoble, 1988); and interview data from the Niamey focus group and interview with local government official of Ayorou, 2019.

87 This information is from the author's personal correspondence with a reporter who was working on a story on the rebellion ongoing in the region of Agadez in 2007. The Tuareg men interviewed by the reporter supported the rebellion but were from the Niger-Mali border 
This history surfaces in the interviews conducted for this study. When plundering cattle, Tuareg marauders would refer to this as a tax, in reference to the notion that the country belonged to them. The word used is jangal (a Fulani word for cattle tax), not zakkat. ${ }^{88}$ According to one interviewee, this behavior became more egregious during the Tuareg rebellions of the 1990s that claimed the region as part of "Tuareg country. ${ }^{89 "}$

A former Fulani militiaman the author, Dr. Idrissa, interviewed for another research effort in June 2019 said that back in the 1980 s cattle raiding occurred only within Malian territory, partly because Niger's strongman of the period, Gal. Seyni Kountché, was willing and able to protect the border. This interviewee also offered a "material" explanation for what he saw as banditry: Mali's security personnel at a remote outpost from Bamako felt free to assist in the plundering, because stolen Nigerien cattle fetched good prices in markets in southern Mali. ${ }^{90} \mathrm{He}$ also stressed that the Fulani engaged in similar behavior too, initially by way of retaliation and afterward because some took a taste for it.

The rebellion of the MNLA, the Malian Tuareg separatist movement that started the wars in 2012, was seen as a direct threat by the Fulani local elite. Its stated objective was to revive the old "Tuareg country," which could happen only at the expense of other groups in the area. Its initial successes alarmed especially the border-residing Fulani communities, leading them to align with the Fulani-dominated jihadist outfit, the Movement for Oneness and Jihad in West Africa (MOJWA), which saw a very large influx of Fulani combatants from the Mali-Niger border in 2012-13. Later, open French military support for some of the separatist Tuareg militia (MSA and the Imghad Tuareg Self-Defense Group and Allies (GATIA)), ${ }^{91}$ especially as it was not seen to be counterpoised by governments in Niamey and Bamako, further entrenched the Fulani in their alliance with jihadists.

\section{Political change}

The second wave of central change occurred in the 1990s. In the colonial and post-colonial eras, governments relied on a reinvented chieftaincy system to keep the peace across the rural areas. This was less true for the First Republic (1960-74) that ruled Niger in the era of modernization theories and consequently sought to unseat "feudalism," as the chieftaincy system was then labelled. The military regime

region, not from Agadez. Lidya Polgreen, personal correspondence with author. See also elsewhere in the region (northern Mali): Pierre Boilley, Les Touareg Kel Adagh. Dépendances et révoltes: du Soudan français au Mali contemporain (Paris: Karthala, 1999), 292-293; André Bourgeot, Les Sociétés touarègues. Nomadisme, identité, résistances (Paris: Karthala, 1995), 356; Normand, "Le Sahel peut-il retrouver la paix?."

88 The sociolinguistic distinction is important in identifying why and how Tuareg groups became rhetorically aligned with Islamist militants, from the perspective of their ethnic competitors.

89 From a collective interview with local chiefs, 2019.

90 Interview with a gentleman from Gao conducted in Bamako in July 2019 for a different project (research on migration networks funded by the Friedrich Ebert Stiftung) confirmed this. See: Rahmane Idrissa, Un dialogue sur fond de divergence: L'impact de la politique migratoire européenne sur l'integration Ouest-Africaine. Les cas du Nigeria, du Mali et du Niger (Berlin: Friedrich-Ebert-Stiftung, Section Afrique, 2019), http://library.fes.de/pdf-files/iez/15340.pdf.

91 The history reported above suggests that the favorable impressions that the French military had about Tuareg military valor from their first entry in the region still hold or were holding in the early 2010 s. 
(1974-91) returned to supporting the chiefs for pragmatic reasons, primarily as assistants in its rural development policy. Democratization in 1991 reopened the case against the chiefs, this time in the name of liberalism (freedom and human rights). It was thought that authority should come from the consent of the people, not from "tradition." The impact of this change became strong for chiefs when decentralization (i.e. democratization at local levels) was launched in the early 2000s, with the first local elections held in 1999. While in many parts of the country the outcome of this change was chiefs learning to live with elected officials who might not be beholden to them, in the agropastoral areas it resulted in the revolt of those suffering from the stigma and, in some cases, the realities of a servile condition.

As soon as Niger adopted democracy, a national association, Timidria ("solidarity" in Tamashaq, the Tuareg language), founded in 1991 by the traditional bonded classes, rapidly scored successes that threatened the position of the traditional master classes, especially among the Tuareg. For instance, in the agropastoral districts of Tahoua, "Black" Tuareg turned the chieftaincy system to their advantage by petitioning for the creation of new, "Black"-run chieftaincies that depleted the older ones of their administrés ("governed"). We have seen that in Inates, the timidria between "Black" Tuareg gave them control of the municipality, i.e. in the democratic context the real local authority. The social-revolutionary character of this change stoked bile among the Tuareg elite and might have invited violence.

However, in the early 2010s, Niger's government under President Mahamadou Issoufou threw the doors of the state wide open for elite Tuareg, thus creating reassurances to them. Since 2011, the prime minister has been a Tuareg politician from the traditional establishment of the region of Agadez, and many higher echelons of the state were populated by people with a similar background. This created the aggrieved perception among "Black" Tuareg that the central government would still tend to side with the "masters" class. A similar perception grew in local settings with more satisfaction among elite Tuareg. In this way, polarization along the status divide hardened across the agropastoral regions. ${ }^{92}$

These cleavages set the stage for the current context-the underlying vulnerability hidden by the systems of moderation that limited violence-but failed to address deep-rooted grievances against the advancing democratization of state power, imbalanced economic power between pastoralists and farmers, and legacy enmities based as much on class and social function as ethnic background. As the state is receding as a legitimate actor in border communities and suffers further damage during the ongoing military action against insurgents, with accompanying human rights abuses of civilians by state security actors, it is losing its ability to serve the role of a third-party interlocutor between communities. This vacuum was filled by insurgents, imposing their rule through hostage taking, targeted killings, and periodic outrages following mass killings - these last could be interpreted as punishing communities for intransigence as well as competing for notoriety with other militant actors.

These developments-especially the clash between local democracy and traditional hierarchies-may not necessarily lead to violence, in fact they did not in other parts of Niger's Sahel-Sahara. ${ }^{93}$ In the border

92 These deductions come from local primary data and observations of the author.

93 It is likely, however, that the early defeat of the MNLA at the hands of Jihadist groups in Mali helped stem the expansion of violence into Niger. Conceivably, an MNLA success in northern Mali would have led to copycat movements in parts of Niger's Sahel-Saharan regions. 
region, however, the urgencies created by the tangle of conflicts that had plunged northern Mali into insurrectionary warfare engulfed the resident Nigerien communities. In the more polarized, Tuareg and Fulani communities people had to choose a camp, and many among the "Black" Tuareg turned toward ethnicity-based allegiances across the border and against the state of Niger that appeared to be siding with their oppressors. It is unclear how the state will be able to reprise its moderating role in the future.

\section{RECOMMENDATIONS}

The contrast observed between Ayorou and Abala demonstrates that local contextual understanding is key. The following recommendations provide considerations for Nigerien state actors, central and local, and external partners to restore the balance and alleviate exacerbating conflict dynamics in the Tillabéry region.

First, a better understanding of the sociopolitical issues may lead the central government to develop an approach to the conflicts that may stem their spread. The reality of economic interdependence means that the conflicts are damaging for all communities. In Abala, it has proved possible to work a policy through that reality and improve the situation to the extent that enemies are now trading on the marketplace. In Ayorou, the grievances of "Black" Tuareg need to be considered for any process of deradicalization to become possible. In particular, interdependence based on legacy master-slave relationship hierarchies needs to be eradicated. This requires contextually specific local political economy analysis to unravel the threads of interdependence, negotiation, and cooperation over resources. Given that interand intracommunal relations are complex and sensitive yet vital to peacekeeping, state agents, especially those working in the security sector, should be trained to learn and understand the culture and histories of the locales where they are posted-in addition to addressing corruption and abuses.

To step up crisis prevention, conflict analysis, and peacebuilding efforts already in place one route might be to expand the capacity of HACP or support the establishment of an HACP-like agency that does not focus only on emergency but also looks into caste- and class-related political issues. Any expansion of HACP mandates must be sensitive to pre-existing perceptions that the HACP is more attuned to elite concerns.

Second, to work toward regaining the conditions of balance, the interplay of institutional mechanisms need to improve. In Abala, the state of violence comparatively decreased because the two key institutional mechanisms for keeping the balance in the rural areas, the local elected officials-the deputy mayor in particular - and the traditional authorities were on the same page, and the gendarmerie were perceived to perform better and provide greater support. From the research it is unclear if there was a systemic basis for this effective cooperation. More research, perhaps social network analysis, could tease out the precise nature of the interactions between personal relationships at the local level and their feedback into formal governance structures. 
This better performance of the gendarmerie in Abala may derive from the topography of institutions compared to Ayorou. In Abala, the gendarmerie precinct is in the central area of the town, close to the town hall and other public buildings. In Ayorou, the gendarmerie precinct is for all practical purposes outside of the town. The physical distance appears to have resulted in a psychological barrier, which may contribute to the dimmer views of people in Ayorou on the gendarmerie in contrast with Abala. In Inates, the local elected officials and the traditional authorities are at loggerheads. Therefore, while there is evidence of institutional cooperation in Abala, the perception in Ayorou is that institutions are rather a source of conflict.

The resolution of the issues that perpetuate war in the border region is a political matter. It will depend on the political vision and abilities of the national leadership. It is easier to make recommendations on what would make implementation of such a vision simpler. The recommendations fall under two broad categories: (1) mending the institutional mechanisms to keeping or restore a peace-supporting balance (chiefs, rural security personnel, elected officials); and (2) developing a campaign of persuasion targeting the radicalized or those belonging into groups most susceptible to radicalization. The recommendations are summarized from insights collected from interviews and a focus group.

On the first score, the Nigerien government should professionalize the traditional chiefs. 2008 and 2010 laws already gave a formal status to chiefs as agents of the territorial administration. While chiefs may resist further formalization as destructive of their informal privileges-while accepting the formal perquisites provided in their legal status - the real resistance comes from the central government, partly because further formalization will imbue the chieftaincy with the kind of institutional autonomy that would reduce their current vulnerability to politicization and manipulations. ${ }^{94}$ Professionalization of the chieftaincy is a demand from the governed, as often expressed in focus groups. High professional standards would increase the trust that chiefs need to act in complex social settings and not be suspected of being beholden to sectional interests or of being mouthpieces of the rulers of the day. This should be the case especially of proximity chiefs (village, tribu), who are the least professional and the least integrated in the administrative scheme.

To establish that local elected officials are the real local authorities in an era of democracy, ${ }^{95}$ their mandate should be extended to land issues. Land issues are still a preserve of chiefs, after they have managed to get ahold of them at the eleventh hour in the democratization debates in 1993. At the time, this was more easily done because Niger had not yet embarked on decentralization. Land issues, including access to natural resources, i.e. demarcation between pasturelands and farmlands, would become less of a source of conflict if they were subjected to local democracy with the norms of accountability, transparency, and publicity that govern rules of decision in that dispensation.

94 Chiefs are under the ministry of the interior and are often seen as strategic assets during electoral campaigns. Ruling parties use powers of incumbency to remove or promote chiefs and sometimes create new chieftaincies. Other politicians-deputies from both majority and opposition -interfere in chieftaincy affairs for patronage in a rural constituency.

95 They are the local equivalents of the national government and the national assembly, which do not have to contend with a traditional king or emperor. The professionalization of traditional chiefs would make such a clarification easier. 
On the second score, people interviewed for this study all insisted on the importance of developing and communicating a message of peace. The national leadership should develop its vision in that regard and launch and maintain a sustainable campaign of persuasion. Events can include recurrent forums of the kind that had resulted in an agreement in Abala in September 2019 and was held in the form of a cultural festival. The emotional appeal of culture is key in this context, especially as a response to the Salafist message. Messaging through social networks ${ }^{96}$ and other informational techniques adapted to the context will strengthen the strategy.

Given the enduring grievances between and within ethnic groups, and how these grievances can motivate youths from across ethnic groups to join or support militancy and jihadism, policymakers may be inclined to attempt ethnic-specific interventions. However, from the perspective of interviewees, the main barriers they perceive to inter- and intracommunal conflict resolution stem from their perceived inability to participate in the public square (due to inequities in democratic processes or safety concerns) and their lack of access to decisionmakers (due to absence or distance from the capital where macro security policy is made). Policymakers should be cautious of assumptions of how individual radicalization does and does not correlate to community motivations for violence or peace and instead support platforms allowing local communities to articulate their needs, frustrations, and potential solutions.

Lastly, and crucially, any vision informing policy from the government and outside intervenors must take account of the legitimacy of the grievances of "Black" Tuareg and Fulani pastoralists. This is not the case at present, since both the state of Niger and its Western allies-France especially-view these groups as "terrorists" and treat them with a hostility that further solidifies their alliance with Salafist militants. Recent events such as a documented massacre of 102 "Black" Tuareg and Fulani pastoralists by the Niger army late March 2020 around Inates and Ayorou $^{97}$ only underscore the urgency of a policy turn supported by the Nigerien state and its geopolitical allies and partners on the basis of these recommendations.

\section{CONCLUSION}

The proliferation of armed groups and escalating intercommunal violence exposes how external actors exploit long-term sites of contestation and governance failure and other fissures that developed over time as populations expanded and livelihoods changed. The proliferation of groups also exposes how the mechanisms communities rely on at the local levels to limit violence and conflict are deeply reliant on the presence of a third party (in this case the state) to provide additional conflict management support where these mechanisms fail. Competition over resources (both within pastoralist communities and between pastoralists and farmers), demographic growth, and environmental degradation and mismanagement created an intractable situation that the government failed to address and armed groups took advantage of. These armed groups were able to mobilize communities against each other on the basis of initial grievances. As the conflict continued, the focus of the groups changed to subsistence, largely through

96 Social networks are used by violent extremists for their own campaigns.

97 Mondafrique, "Niger, cent deux civils massacrés puis ensevelis dans des fosses communes," April 22, 2020, https://mondafrique.com/ niger-cent-deux-hommes-massacres-puis-ensevelis-dans-des-fosses/. 
adopting coercive criminal organizational methods and tactics. Extortion, theft, tax, and targeted killings (reminiscent of mafia tactics) demonstrate how jihadists were able to coopt CBAG-like groups away from community protection or score settling into criminal groups and terrorist affiliates.

Armed community mobilization and ethnically affiliated community-based armed groups in Niger in their current form must be viewed as a result of the breakdown in hybrid sociopolitical mechanisms that maintained a precarious balance across several Tuareg rebellions and reformations of local governance processes. The shifting role of traditional chiefs in a process of democratization and decentralization; changing demographics increasing the representative power of farmers versus herders; and the shortterm alliances between both western military forces and militant groups are all part and parcel to the complicated security environment in the Nigerien-Malian borderlands. In seeking solutions to escalating insecurity, it is imperative that policymakers and practitioners heed the fruits of historic interdependent economic and political relations and beware inflaming equally historic grievances between and within the diverse populations that call Niger home. 


\section{BIBLIOGRAPHY}

Abadie, Maurice. La Colonie du Niger. Afrique centrale. Paris: Société d’éditions géographiques, maritimes et coloniales, 1927.

Afrobarometer. "Résumé des résultats. Sixième série de l'enquête Afrobaromtère au Niger, 2015." LASDEL, April 2015. http://afrobarometer.org/sites/default/ files/publications/Summary\%20of\%20results/ngr-r6-sor.pdf.

Armstrong, Hannah. "Behind the Jihadist Attack in Niger's Inates." International Crisis Group, December 13, 2019. https://www.crisisgroup.org/africa/sahel/ niger/behind-jihadist-attack-inates.

Barry, Abdoul W., B. Lynn Salinger, and Selina Pandolfi. "Sahelian West Africa: Impact of Structural Adjustment Programs on Agricultural Competitiveness and Regional Trade." African Economic Policy Discussion Paper Number 37, December 2000. http://hubrural.org/IMG/pdf/usaid impact structural adjustments on ag competitiviness.pdf

Bernier, Xavier. "Les consequences des sécheresses récentes sur le développement agropastoral au nord de Filingué (Niger)." Thesis, Université Joseph Fourie, Grenoble, 1988.

Boilley, Pierre. Les Touareg Kel Adagh. Dépendances et révoltes: du Soudan français au Mali contemporain. Paris: Karthala, 1999.

Bourgeot, André. Les Sociétés touarègues. Nomadisme, identité, résistances. Paris: Karthala, 1995.

Food and Agriculture Organization of the United Nations (FAO). "Information system on pastoralism in the Sahel: Atlas of trends in pastoral systems in the Sahel 1970-2012." 2012. http://www.fao.org/3/i2601e/i2601e.pdf.

Glenn, Cameron, Mattisan Rowan, John Caves, and Garrett Nada, “Timeline: the Rise, Spread, and Fall of the Islamic State," Wilson Center, The Islamists, 2016. https://www.wilsoncenter.org/article/timeline-the-rise-spread-and-fall-the-islamic-state.

Guichaoua, Yvan. “Mali-Niger: une frontière entre conflits communautaires, rebellion et djihad." Le Monde, June 20, 2016. https://www.lemonde.fr/afrique/ article/2016/06/20/mali-niger-une-frontiere-entre-conflits-communautaires-rebellion-et-djihad $49540853212 . \mathrm{html}$.

Gouvernement de la République du Niger. Le Programme d'action du Niger 2001-2010. Conference document, United Nations, 2000.

Hahonou, E. K. Les Pouvoirs locaux à Balleyara. Niamey: LASDEL, 2002.

Haute Autorité à la Consolidation de la Paix (HACP). “Mission de la HACP.” Accessed March 25, 2021. http://www.hacp-niger.org/.

Hoinathy, Remadji, and Daniel Eizenga. The State of Secularism in Chadian Higher Education: Testing Perceived Ties to Violent Extremism. Washington, D.C.: RESOLVE Network, 2019. https://doi.org/10.37805/lcb2019.2.

Hourst, Émile. La Mission Hourst sur le Niger et au pays des Touareg. Paris: Plon, 1898.

Human Rights Watch. "Sahel: End Abuses in Counterterrorism Operations." February 13, 2021. https://www.hrw.org/news/2021/02/13/ sahel-end-abuses-counterterrorism-operations.

Idrissa, Rahmane. "Traditional authorities in Niger: Politicization and under-representation." In The Status Quo Defied: The Legitimacy of Traditional Authorities in Areas of Limited Statehood in Mali, Niger and Libya, edited by Fransje Molenaar, Jonathan Tossell, Anna Schmauder, Abdourahmane Idrissa, and Rida Lyammouri, 52-73. The Hague: Clingendael Institute, 2019. https://www.clingendael.org/pub/2019/ legitimacy traditional_authorities_mali_niger_libya/.

Idrissa, Rahmane. Un dialogue sur fond de divergence: L'impact de la politique migratoire européenne sur l'integration Ouest-Africaine. Les cas du Nigeria, du Mali et du Niger. Berlin: Friedrich-Ebert-Stiftung, Section Afrique, 2019. http://library.fes.de/pdf-files/iez/15340.pdf.

International Crisis Group. "Sidelining the Islamic State in Niger's Tillabery." June 3, 2020. https://www.crisisgroup.org/africa/sahel/ niger/289-sidelining-islamic-state-nigers-tillabery.

IRIN News. "Briefing: The new Jihadist strategy in the Sahel." Africa Renewal, February 4, 2016. https://www.un.org/africarenewal/sahel/news/ briefing-new-jihadist-strategy-sahel.

Jamart, Clara. "Niger's Rural Code and the Pastoralist Issue." AGTER, March 2011. https://www.agter.org/bdf/en/corpus chemin/fiche-chemin-91.html.

Lund, Christian. "Precarious democratization and local dynamics in Niger: micro-politics in Zinder." Development and Change 32, no. 5 (2001): 845-69. https:// doi.org/10.1111/1467-7660.00229.

McGann, Bethany. "Hybridity and Fragmentation: Implications for Regional Security Policy in the Sahel and Beyond." In Extremisms in Africa Volume 3, edited by Stephen Buchanan-Clarke, Lloyd Coutts, Susan Russell, Alain Tschudin, and Craig Moffat, 284-313. Good Governance Africa, 2020.

Mohamadou, Abdoulaye. "Foncier, pouvoirs locaux et décentralisation dans le département de Dakoro (Niger)." Bulletin de l'APAD, 31-32 (2010): 105-136. https://doi.org/10.4000/apad.4052.

Molenaar, Fransje, Jonathan Tossell, Anna Schmauder, Abdourahmane Idrissa, and Rida Lyammouri. The Status Quo Defied: The Legitimacy of Traditional Authorities in Areas of Limited Statehood in Mali, Niger and Libya. The Hague: Clingendael Institute, 2019. https://www.clingendael.org/pub/2019/ legitimacy traditional_authorities_mali_niger_libya/. 
Molenaar, Fransje, Jonathan Tossell, Anna Schmauder, Abdourahmane Idrissa, and Rida Lyammouri. "The historical trajectory of traditional authority structures in Mali, Niger and Libya." In The Status Quo Defied: The Legitimacy of Traditional Authorities in Areas of Limited Statehood in Mali, Niger and Libya, edited by Molenaar, Fransje, Jonathan Tossell, Anna Schmauder, Abdourahmane Idrissa, and Rida Lyammouri, 26-52. The Hague: Clingendael Institute, 2019. https://www.clingendael.org/pub/2019/ legitimacy traditional authorities mali niger libya/2-the-historical-trajectory-of-traditional-authority-structures-in-mali-niger-and-libya/.

Mondafrique. "Niger, cent deux civils massacrés puis ensevelis dans des fosses communes." April 22, 2020. https://mondafrique.com/ niger-cent-deux-hommes-massacres-puis-ensevelis-dans-des-fosses/.

Niger24.org. "Forum de Banibangou: Prévenir et gérer les conflits grâce au dialogue intercommunautaire." Niamey.com, August 14, 2013. http://news.aniamey. $\underline{\mathrm{com} / \mathrm{h} / 3757 . \mathrm{html}}$.

Normand, Nicolas. "Le Sahel peut-il retrouver la paix?." Commentaire 4, no. 164 (2018): 839-846.

Olivier de Sardan, Jean-Pierre. Les Sociétés songhay-zarma, Niger-Mali: chefs, guerriers, esclaves, paysans. Paris: Karthala, 1984.

Oumarou, Hamani, La Construction du 'local' et la gouvernance communale par le bas. L'exemple de la commune rurale de Banibangou (Niger). Niamey: LASDEL, 2011.

Oxford Research Group. "The Military Intervention in Mali and Beyond: An Interview with Bruno Charbonneau." March 28, 2019. https://www.oxfordresearchgroup.org.uk/blog/the-french-intervention-in-mali-an-interview-with-bruno-charbonneau.

Peace Insight. “Timidria, L’Association de Défense des Droits de L'Homme et de Développement." https://www.peaceinsight.org/conflicts/niger/ peacebuilding-organisations/timidria/.

Radio France Internationale. “AQMI, MUJAO, MNLA: un rapport de force complexe." July 5, 2012. https://www.rfi.fr/fr/ afrique/20120705-aqmi-mujao-mnla-rapport-force-complexe.

Radio France Internationale. "Niger: les jihadistes ciblent les chefs de village." November 24, 2019. http://www.rfi.fr/fr/ afrique/20191124-niger-jihadistes-chefs-villages

Raynaut, Claude, and Souleymane Abba. "Trente ans d'indépendances: repères et tendances." Politique Africaine, 38 (June 1990): 3. https://f-origin.hypotheses.org/wp-content/blogs.dir/1629/files/2020/05/038003.pdf.

Rhissa, Zakary. Revue du secteur de l'élevage au Niger. FAO/SFW, 2010. https://reca-niger.org/IMG/pdf/Niger_Revue national.pdf.

Rossi, Bendetta. From Slavery to Aid. Politics, Labour, and Ecology in the Nigerien Sahel, 1800-2000. Cambridge: Cambridge University Press, 2015.

Stewart, Scott. “Mali Besieged by Fighters Fleeing Libya." Stratfor Worldview, February 2, 2012. https://worldview.stratfor.com/article/ mali-besieged-fighters-fleeing-libya.

Tidjani Alou, Mahaman S. “Decentralization in Niger: An Attempted Approach.” Columbia University, 1999. https://www.ciesin.columbia.edu/decentralization/ English/CaseStudies/Niger.pdf.

Tidjani Alou, Mahaman. La Chefferie au Niger et ses transformations. Niamey: LASDEL, 2009.

United Nations Security Council. "Islamic State in the Greater Sahara (ISGS)." https://www.un.org/securitycouncil/content/islamic-state-greater-sahara-isgs.

Van Metre, Lauren. From Self-Defense to Vigilantism: A Typology Framework of Community-Based Armed Groups. Washington, D.C.: RESOLVE Network, 2019. https://doi.org/10.37805/cbags2019.3.

Villalón, Leonardo, and Rahmane Idrissa. "A Decade of Experimentation. Institutional Choices and Unstable Democracy in Niger." In The Fate of Africa Democratic Experiments. Elites and Institutions. Edited by Leonardo Villalón and Peter VonDoepp, 27-48. Bloomington and Indianapolis: Indiana University Press, 2005.

Vellturo, Madeline. "Fulani and Jihad in West Africa: a complex relationship." Good Governance Africa, October 13, 2020. https://gga.org/ fulani-and-jihad-in-west-africa-a-complex-relationship/.

Schweitzer, Yoram. "Palestinian Female Suicide Bombers: Reality Vs. Myth.” Memorandum No. 84. Jaffee Center for Strategic Studies at Tel Aviv University, 2006

Sjoberg, Laura and Caron Gentry. Mothers, Monsters, Whores: Women's Violence in Global Politics. London: Zed Books, 2007.

Sjoberg, Laura and Caron Gentry. Women, Gender, and Terrorism. Athens: University of Georgia Press, 2009.

Sidibé, Kalilou. "Security Management in Northern Mali: Criminal Networks and Conflict Resolution Mechanisms." IDS Research Reports 77 (2012): 1-103.

Specht, Irma. Red Shoes: Experiences of Girls-Combatants in Liberia. International Labour Office, Geneva, 2006.

Stack, Alisa. "Zombies versus Black Widows: Women as Propaganda in the Chechen Conflict." In Women, Gender and Terrorism, edited by Laura Sjoberg and Caron E. Gentry, 83-95. University of Georgia Press, 2011.

Steim, Judith. "The Effect of Myths about Military Women on the Waging of War." In Women and the Military System, edited by Eva Isaksson. New York: St. Martin's, 1988. 
Straus, Scott. Making and Unmaking Nations: War, Leadership, and Genocide in Modern Africa. Cornell University Press, 2015.

Tamaru, Nanako and Marie O’Reilly. “How Women Influence Constitution Making After Conflict and Unrest.” Inclusive Security, January 2018.

Trisko Darden, Jessica, Alexis Henshaw, and Ora Szekely. Insurgent Women: Female Combatants in Civil Wars. Georgetown University Press, 2019.

Thomas, Jakana L. and Kanisha D. Bond. “Women's Participation in Violent Political Organizations," American Political Science Review 109, no. 3 (2015): 488-506.

Thomas, Jakana L. and Reed M. Wood. "The Social Origins of Female Combatants.” Conflict Management and Peace Science 35, no. 3 (2018): $215-232$.

Tripp, Aili Mari, Casimiro, Isabel, Kwesiga, Joy and Mungwa, Alice. “African Women's Movements." In Changing Political Landscapes. Cambridge University Press, 2009.

Tripp, Aili Mari. Women and Power in Post-Conflict Africa. Cambridge University Press, 2015.

United States Department of State. "2017 Trafficking in Persons."

Uchendu, Egodi. Women and conflict in the Nigerian Civil War. Trenton, NJ: Africa World Press, 2007.

Utas, Mats. “Sweet Battlefields: Youth and the Liberian Civil War.” Uppsala University Dissertations in Cultural Anthropolgy, Uppsala University, 2003.

Van Metre, Lauren. From Self-Defense to Vigilantism: A Typology Framework of Community-Based Armed Groups. Washington, D.C.: RESOLVE Network, 2019. https://doi.org/10.37805/cbags2019.3.

Van Allen, Judith. "Aba Riots or the Igbo Women's War? Ideology, Stratification and the Invisibility of Women." Ufahamu: A Journal of African Studies 6, no. 1 (1975): 11-39.

Victor, Barbara. Army of Roses: Inside The World of Palestinian Women Suicide Bombers. Perseus Books Group, 2003.

Viterna, Jocelyn. Women in War: The Microprocesses of Mobilization in El Salvador. Oxford University Press, 2013.

Warner, Jason and Hilary Matfess. "Exploding Stereotypes: The Unexpected Operational and Demographic Characteristics of Boko Haram's Suicide Bombers." Combating Terrorism Center, 2017.

“Watchmen of Lake Chad: Vigilante Groups Fighting Boko Haram,” International Crisis Group, no. 244 , February 2017.

Watson, Ruth. “'Ibadan-A Model of Historical Facts': Militarism and Civic Culture in a Yoruba City.” Urban History (1999): 5-26.

Wood, Elisabeth Jean. "The Social Processes of Civil War: The Wartime Transformation of Social Networks." Annual Review of Political Science 11 (2008): 539-661.

Wood, Reed M. Female Fighters: Why Rebel Groups Recruit Women for War. Columbia University Press, 2019.

Wood, Reed M. and Jakana L. Thomas. "Women on the Frontline: Rebel Group Ideology and Women's Participation in Violent Rebellion." Journal of Peace Research 54, no. 1 (2017): 31-46. 


\section{About the Authors}

Dr Abdourahmane (Rahmane) Idrissa is a political scientist at the African Studies Centre at Leiden University. He holds a doctorate in political science from the University of Florida. Idrissa's research expertise ranges from issues of states, institutions, and democratization in Africa to Salafi radicalism in the Sahel and the history of state formation in Africa, with a focus both on the modern (Niger) and premodern eras (Songhay). Idrissa is also associated with the Niamey based social science laboratory LASDEL, runs the think tank EPGA and is on the editorial board of the African Studies Quarterly at the University of Florida.

Bethany L. McGann was a program officer at the U.S. Institute of Peace, leading the Africa research portfolio with the RESOLVE Network, the research component of the Violent Extremism team within the Center for Applied Conflict Transformation. She joined USIP in 2014, supporting its work on governance, justice, and the rule of law before joining the RESOLVE Network team in 2016. McGann led the design and implementation of multi-year USAID funded desk and field studies focused on; Sahelian sub-state hybrid armed actors, militias and local security assemblages; the role of women in armed community mobilization in East and West Africa; and local peacebuilding mechanisms in violent extremism affected contexts. 


\section{RESOLVE NETWORK}

better research.informed practice.improved policy on violent extremism.

www.resolvenet.org

$y$ in. 


\section{RESOLVE /}

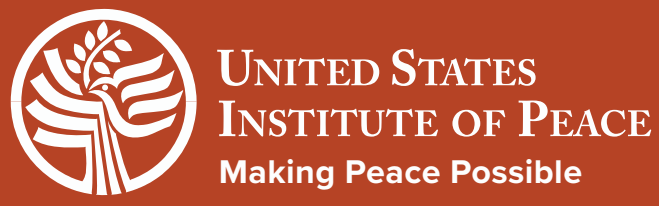

